\title{
DIGITAL SPEECH AND DEMOCRATIC CULTURE: A THEORY OF FREEDOM OF EXPRESSION FOR THE INFORMATION SOCIETY
}

\begin{abstract}
JACK M. BALKIN*
In this essay, Professor Balkin argues that digital technologies alter the social conditions of speech and therefore should change the focus of free speech theory, from a Meiklejohnian or republican concern with protecting democratic process and democratic deliberation, to a larger concern with protecting and promoting a democratic culture. A democratic culture is a culture in which individuals have a fair opportunity to participate in the forms of meaning-making that constitute them as individuals. Democratic culture is about individual liberty as well as collective selfgovernance; it concerns each individual's ability to participate in the production and distribution of culture. Balkin argues that Meiklejohn and his followers were influenced by the social conditions of speech produced by the rise of mass media in the twentieth century, in which only a relative few could broadcast to large numbers of people. Republican or progressivist theories of free speech also tend to downplay the importance of nonpolitical expression, popular culture, and individual liberty. The limitations of this approach have become increasingly apparent in the age of the Internet.
\end{abstract}

By changing the social conditions of speech, digital technologies lead to new social conflicts over the ownership and control of informational capital. The free speech principle is the battleground over many of these conflicts. For example, media companies have interpreted the free speech principle broadly to combat regulation of digital networks and narrowly in order to protect and extend their intellectual property rights. The digital age greatly expands the possibilities for individual participation in the growth and spread of culture, and thus greatly expands the possibilities for the realization of a truly democratic culture. But the same technologies also produce new methods of control that can limit democratic cultural participation. Therefore, free speech values-interactivity, mass participation, and the ability to modify and transform culture-must be protected through technological design and through administrative and legislative regulation of technology, as well as through the more traditional method of judicial creation and recognition of constitutional rights. Increasingly, freedom of speech will depend on the design of the technological infrastructure that supports the system of free expression and secures widespread democratic participation. Institutional limitations of courts will prevent them from reaching the most important questions about how that infrastructure is designed and implemented. Safeguarding freedom of speech will thus increasingly fall to legislatures, administrative agencies, and technologists.

INTRODUCTION: NOVELTY AND SALIENCE

* Copyright (C) 2004 by Jack M. Balkin. Knight Professor of Constitutional Law and the First Amendment, Yale Law School. My thanks to Bruce Ackerman, Yochai Benkler, Owen Fiss, Eddan Katz, Nimrod Kozlovski, Orly Lobel, Guy Pessach, Robert Post, Reva Siegel, Gunther Teubner, Rebecca Tushnet, Tal Zarsky, and Jonathan Zittrain for their comments on previous drafts. 
What do digital technologies teach us about the nature of freedom of speech? How should our theories of freedom of expression change to take these technologies into account? In this essay, I argue that the Internet and digital technologies help us look at freedom of speech from a different perspective. That is not because digital technologies fundamentally change what freedom of speech is. Rather, it is because digital technologies change the social conditions in which people speak, and by changing the social conditions of speech, they bring to light features of freedom of speech that have always existed in the background but now become foregrounded.

This effect-making more central and visible what was already always present to some degree-is important in any study of the Internet and digital technologies. In studying the Internet, to ask "What is genuinely new here?” is to ask the wrong question. If we assume that a technological development is important to law only if it creates something utterly new, and we can find analogues in the past—as we always can-we are likely to conclude that because the development is not new, it changes nothing important. ${ }^{1}$ That is the wrong way to think about technological change and public policy, and in particular, it is the wrong way to think about the Internet and digital technologies.

Instead of focusing on novelty, we should focus on salience. What elements of the social world does a new technology make particularly salient that went relatively unnoticed before? What features of human activity or of the human condition does a technological change foreground, emphasize, or problematize? And what are the consequences for human freedom of making this aspect more important, more pervasive, or more central than it was before?

The digital revolution places freedom of speech in a new light, just as the development of broadcast technologies of radio and television did before it. The digital revolution brings features of the system of free expression to the forefront of our concern, reminding us of things about freedom of expression that were always the case, but now have become more central and thus more relevant to the policy issues we currently face. The digital revolution makes possible widespread cultural participation and interaction that previously could not have existed on the same scale. At the same time, it creates new opportunities for limiting and controlling those forms of cultural participation and interaction. The digital age makes the

1 See, e.g., Frank H. Easterbrook, Cyberspace and the Law of the Horse, 1996 U. CHI. LEGAL F. 207, 216 (arguing that clear rules, property rights, and facilitating bargains will resolve regulatory problems in cyberspace much as they do in real space); Joseph H. Sommer, Against Cyberlaw, 15 BERKELEY TECH. L.J. 1145, 1148 (2000) (“[F]ew of the legal issues posed by the new informatics technologies are novel.”). 
production and distribution of information a key source of wealth. Therefore it creates a new set of conflicts over capital and property rights that concern who has the right to distribute and gain access to information. Not surprisingly, the free speech principle sits at the center of these conflicts. Freedom of speech is rapidly becoming the key site for struggles over the legal and constitutional protection of capital in the information age, and these conflicts will shape the legal definition of freedom of speech. The digital revolution offers unprecedented opportunities for creating a vibrant system of free expression. But it also presents new dangers for freedom of speech, dangers that will be realized unless we accommodate ourselves properly to the changes the digital age brings in its wake. The emerging conflicts over capital and property are very real. If they are resolved in the wrong way, they will greatly erode the system of free expression and undermine much of the promise of the digital age for the realization of a truly participatory culture.

Digital technologies highlight the cultural and participatory features of freedom of expression. In this essay, I offer a theory of freedom of speech that takes these features into account. The purpose of freedom of speech, I shall argue, is to promote a democratic culture. A democratic culture is more than representative institutions of democracy, and it is more than deliberation about public issues. Rather, a democratic culture is a culture in which individuals have a fair opportunity to participate in the forms of meaning making that constitute them as individuals. ${ }^{2}$ Democratic culture is about individual liberty as well as collective self-governance; it is about each individual's ability to participate in the production and distribution of culture.

Freedom of speech allows ordinary people to participate freely in the spread of ideas and in the creation of meanings that, in turn, help constitute them as persons. A democratic culture is democratic in the sense that everyone-not just political, economic, or cultural elites-has a fair chance to participate in the production of culture, and in the development of the ideas and meanings that constitute them and the communities and

2 See J.M. Balkin, Populism and Progressivism as Constitutional Categories, 104 YALE L.J. 1935, 1948-49 (1995) (reviewing CASS R. Sunstein, DEMOCRACY AND THE PROBLEM OF FREE SPEECH (1993), and defining democratic culture as popular participation in culture).

Media and popular culture theorist John Fiske has coined the term "semiotic democracy" to describe popular participation in the creation of meanings, often by turning existing forms of mass culture to different uses. JOHN FISKE, TELEVISION CUlTURE 236-39 (1987); see also Michael Madow, Private Ownership of Public Image: Popular Culture and Publicity Rights, 81 CAL. L. REV. 125, 146 (1993) (defining semiotic democracy as "a society in which all persons are free and able to participate actively, if not equally, in the generation and circulation of meanings and values”). Fiske's idea has become particularly important in the intellectual property literature. See infra note 56. 
subcommunities to which they belong. ${ }^{3}$ People have a say in the development of these ideas and meanings because they are able to participate in their creation, growth, and spread.

Like democracy itself, democratic culture exists in different societies in varying degrees; it is also an ideal toward which a society might strive. Freedom of expression protects the ability of individuals to participate in the culture in which they live and promotes the development of a culture that is more democratic and participatory.

Freedom of speech is interactive and appropriative. It is interactive because speech is about speakers and listeners, who in turn become speakers themselves. Speech occurs between people or groups of people; individual speech acts are part of a larger, continuous circulation. People participate in culture by interacting with others and influencing and affecting them through communication. This is obvious in the case of speech directed at persuasion, but is true of all speech. Even when we dislike what someone else is saying, we are often affected and influenced by it. Our exposure to speech, our attempt to understand it, to bring it within our understanding, continually reshapes us. Our continuous participation in cultural communication, our agreement with and reaction to what we experience, our assimilation and rejection of what culture offers us, makes us the sort of people that we are.

Freedom of speech is appropriative because it draws on existing cultural resources; it builds on cultural materials that lay to hand. Dissenters draw on what they dislike in order to criticize it; artists borrow from previous examples and build on artistic conventions; even casual conversation draws on common topics and expressions. People participate in culture through building on what they find in culture and innovating with it, modifying it, and turning it to their purposes. Freedom of speech is the ability to do that. In a democratic culture people are free to appropriate elements of culture that lay to hand, criticize them, build upon them, and create something new that is added to the mix of culture and its resources.

The idea of a democratic culture captures the inherent duality of freedom of speech: Although freedom of speech is deeply individual, it is at the same time deeply collective because it is deeply cultural. Freedom of speech is, in Thomas Emerson's words, a system. ${ }^{4}$ It is a cultural system as well as a political system. It is a network of people interacting with each other, agreeing and disagreeing, gossiping and shaming, criticizing and parodying, imitating and innovating, supporting and praising. People exercise their freedom by participating in this system: They participate by interacting with others and by making new meanings and new ideas out of

3 Balkin, supra note 2, at 1948-49.

4 THOMAS I. EMERSON, THE SYSTEM OF FREEDOM OF EXPRESSION 3 (1970). 
old ones. Even when people repeat what others have said, their reiteration often carries an alteration in meaning or context. ${ }^{5}$ As people express themselves, make music, create works of art, sing, gossip, converse, accuse, deny, complain, celebrate, enthuse, boast, and parody, they continually add something to the cultural mixture in which they live. They reshape, however imperceptibly, cultural conventions about what things mean, what is proper and improper, what is important and less important, how things are done and how they are not done. Through communicative interaction, through expression, through exchange, individual people become the architects of their culture, building on what others did before them and shaping the world that will shape them and those who follow them. And through this practice of interaction and appropriation, they exercise their freedom.

Freedom of speech is thus both individual and cultural. It is the ability to participate in an ongoing system of culture creation through the various methods and technologies of expression that exist at any particular point in time. Freedom of speech is valuable because it protects important aspects of our ability to participate in the system of culture creation. Participation in culture is important because we are made of culture; the right to participate in culture is valuable because it lets us have a say in the forces that shape the world we live in and make us who we are.

The digital age provides a technological infrastructure that greatly expands the possibilities for individual participation in the growth and spread of culture and thus greatly expands the possibilities for the realization of a truly democratic culture. But the same technologies also can produce new methods of control that can limit democratic cultural participation. Therefore, free speech values-interactivity, mass participation, and the ability to modify and transform culture-must be protected through technological design and through administrative and legislative regulation of technology, as well as through the more traditional method of judicial creation and recognition of constitutional rights. Increasingly, freedom of speech will depend on the design of the technological infrastructure that supports the system of free expression and secures widespread democratic participation. Institutional limitations of

5 Cf. Jacques Derrida, Limited Inc a b c ..., in 2 GLYPH 162, 200 (1977) ("Iterability alters[.]”). Jed Rubenfeld expresses a similar idea through the metaphor of imagination. He argues that freedom of speech protects the rights of both authors and readers because acts of imagination are inevitably transformative, both for producers and receivers of cultural objects. Jed Rubenfeld, The Freedom of Imagination: Copyright's Constitutionality, 112 YALE L.J. 1, 37-38 (2002). Rebecca Tushnet points out that repetition of ideas or social scripts can be a way of expressing solidarity with others, support for a favored cause, or one's own sense of propriety as a member of a religious, political, or social group. Rebecca Tushnet, Copyright as a Model for Free Speech Law: What Copyright Has in Common with Anti-Pornography Laws, Campaign Finance Reform, and Telecommunications Regulation, 42 B.C. L. REV. 1, 16-17 (2001). 
courts will prevent them from reaching the most important questions about how that infrastructure is designed and implemented. Safeguarding freedom of speech will increasingly fall to legislatures, administrative agencies, and technologists. Protecting freedom of speech in the digital age will require a new class of cyberlawyers, who understand the impact of technological design on free speech values and can help shape regulatory solutions that promote technologies that, in turn, will help secure the values of free expression.

\section{I}

\section{HOW THE DigitAl AgE CHANGES THE CONDITIONS OF SPEECH}

The next Part of this essay describes how the digital revolution alters our perspective on freedom of speech and leads to a series of disputes about what the free speech principle means. By the "digital revolution,” I mean the creation and widespread availability of technologies that make it easy to copy, modify, annotate, collate, transmit, and distribute content by storing it in digital form. These technologies also include the development of vast communication networks that connect every part of the world for the purpose of distributing digital content. The digital revolution changes the factual assumptions underlying the social organization and social practices of freedom of speech in four important ways.

First, the digital revolution drastically lowers the costs of copying and distributing information. Large numbers of people can broadcast and publish their views cheaply and widely. Websites, for example, are easy to construct and easy to access. We do not yet know how low the costs of information transfer will become. For example, the development of weblogs (or blogs) allows people to publish content to the Internet with the press of a button, lowering the costs of publication and distribution even further.

Before the Internet, free speech theorists worried about the scarcity of bandwidth for broadcast media. Frequencies were limited, so only a relatively few people could broadcast to a large number of people. The digital revolution made a different kind of scarcity salient. It is not the scarcity of bandwidth but the scarcity of audiences, and, in particular, scarcity of audience attention. My speech has always competed with yours; as the costs of distribution of speech are lowered, and more and more people can reach each other easily and cheaply, the competition for audience attention has grown ever more fervent. ${ }^{6}$ An interesting side effect of lowering the costs of distribution and transmission is that it can alter the

6 See Jack M. Balkin, Free Speech From a Meme’s Point of View 8, 13 (Apr. 4, 2003) (unpublished manuscript, on file with New York University Law Review) (explaining rapid growth of expression on Internet in terms of lowered costs of production and distribution of information). 
relative costs of receiving versus sending information. Although receiving information is easier, sending information can become even less costly. The classic example is spam e-mail, which shifts the costs of distribution from speakers to audiences. Because so many people are producing content and sending it everywhere, audiences are pummeled with vast amounts of information which they must collate, sort, filter, and block. Hence, the digital revolution brings to the forefront the importance of organizing, sorting, filtering, and limiting access to information, as well as the cultural power of those who organize, sort, filter, and limit access. ${ }^{7}$

Second, the digital revolution makes it easier for content to cross cultural and geographical borders. Not only can speakers reach more people in the country in which they live, they can also interact with and form new communities of interest with people around the globe. It has long been possible to send information globally, but the cost and effort were comparatively great. The Internet gives people abilities that were previously enjoyed only by large commercial enterprises; it offers them access to an infrastructure for sending information worldwide. ${ }^{8}$

Third, the digital revolution lowers the costs of innovating with existing information, commenting on it, and building upon it. An important feature of the digital revolution is the development of common standards for storing and encoding information digitally. Common standards are absolutely crucial to lowering the costs of transmission and distribution. (We might make a rough analogy to the role of standardization that accompanied the Industrial Revolution.) However, the same features of content that make it possible for people to transmit and distribute information cheaply and easily also make it possible to manipulate, copy, and alter information cheaply and easily. In the past it was always possible to copy a text or a drawing by hand, but such copying was comparatively expensive and time-consuming. Once people have a common metric for storing images, music, and text, they can copy, cut, and paste information and send it to others. Common standards for encoding images, music, and text not only make it easy to copy and distribute content, they also make it easier to appropriate, manipulate, and edit content.

7 See J.M. Balkin, Media Filters, the V-Chip, and the Foundations of Broadcast Regulation, 45 DuKE L.J. 1131, 1145 (1996) ("In the Information Age, the informational filter, not information itself, is king.”); James Boyle, Foucault in Cyberspace: Surveillance, Sovereignty, and Hardwired Censors, 66 U. CIN. L. REV. 177, 194 (1997) (noting that filtering technologies supply state with "a different arsenal of methods with which to regulate content").

8 Lowering the costs of distribution also allows more speakers to reach across existing cultural, geographical, and disciplinary boundaries. It allows information to get past previously closed communities, it enables new communities to form based on existing interests, and it helps create new interests around which communities can form. 
The link between the ability to copy and the ability to modify information is central to understanding the possibilities created by the digital revolution. Consumers of digital media products ${ }^{9}$ are not simply empowered to copy digital content; they are also empowered to alter it, annotate it, combine it, and mix it with other content and produce something new. Software allows people to innovate with and comment on other digital media products, including not only text, but also sounds, photographs, and movies. The standard example is the well-known story of The Phantom Edit, in which an individual reedited George Lucas's Star Wars movie The Phantom Menace to eliminate as much as possible of the screen time devoted to a particularly obnoxious character, Jar Jar Binks. ${ }^{10}$ The Phantom Edit exemplifies what the digital age makes possible. It is not simply piracy; it is also innovation, although certainly not the sort of innovation that LucasFilms was interested in promoting. ${ }^{11}$ This innovation goes hand in hand with the possibility of digital piracy; both are forms of appropriation made possible by digital technologies and digital communications networks. Lowering the costs of both distribution and appropriation are central features of the digital age. Digital media, in short, invite not only simple copying but also annotation, innovation, and collage. ${ }^{12}$

Fourth, and most important, lowering the costs of transmission, distribution, appropriation, and alteration of information democratizes speech. Speech becomes democratized because technologies of distribution and transmission are put in the hands of an increasing number of people and increasingly diverse segments of society throughout the

9 I borrow this term from C. EDWIN BAKER, MEDIA, MARKETS, AND DEMOCRACY 7-14 (2002) (noting important differences between media products and typical non-information goods).

10 On The Phantom Edit, see Richard Fausset, A Phantom Menace?, L.A. TiMES, June 1, 2002, at F1.

11 Asked about the phenomenon by an interviewer, Lucas explained,

[E]verybody wants to be a filmmaker. Part of what I was hoping for with making movies in the first place was to inspire people to be creative. The Phantom Edit was fine as long as they didn't start selling it. Once they started selling it, it became a piracy issue. I'm on the Artist Rights Foundation board, and the issue of non-creators of a movie going in and changing things and then selling it as something else is wrong. Gavin Smith, The Genius of the System: George Lucas Talks to Gavin Smith About Painting by Numbers, Mind-Numbing Minutiae, and Final Cuts, Film Comment, July-Aug. 2002, at 31, 32.

12 James Boyle argues that a characteristic feature of the information society is that an increasing proportion of product cost goes to content creation rather than to distribution, and to message rather than medium. James Boyle, A Politics of Intellectual Property: Environmentalism for the Net?, 47 DUKE L.J. 87, 93-94 (1997). That is not necessarily inconsistent with my argument that digital technologies lower costs of innovation: Both content creation and distribution costs are lowered, but distribution costs decline much more rapidly. In the meantime, digital technologies spur new forms of content creation that would have been prohibitively expensive (or impossible) in the past. 
planet. More and more people can publish content using digital technologies and send it worldwide; conversely, more and more people can receive digital content, and receive it from more and more people. Equally important, speech becomes democratized because technologies of innovation are available to a wider range of people. In the digital age, distribution and innovation go hand in hand.

\section{II}

\section{ROUTING AROUND AND GLOMMING ON}

In the early days of the Internet, many people assumed that the Internet would displace the mass media and publishing houses as traditional gatekeepers of content and quality. This has not occurred. Rather, the Internet has provided an additional layer of communication that rests atop the mass media, draws from it, and in turn influences it.

Mass media are asymmetrical and unidirectional. The ability to broadcast widely is held in relatively few hands; what is broadcast is sent out to a large number of people with very little opportunity for people to talk back. Access to mass media is comparatively limited. Mass media create a technological bottleneck, and the people who control mass media are gatekeepers controlling its use. As a result, in a world dominated by mass media, the recurring problem for people who want to speak effectively and reach large numbers of people is how to gain access to an effective podium. People can purchase access if they own a significant amount of property; in the alternative, they can stage media events to draw the mass media's attention. In the latter case, however, speakers cannot easily control their message.

The Internet offers two different strategies for dealing with the mass media: routing around and glomming on. Routing around means reaching audiences directly, without going through a gatekeeper or an intermediary. For example, you can publish content on your own website or distribute copies of your band's music on the Internet. Routing around relieves the bottleneck problem to some extent, but it does not eliminate it. Mass media are still quite important, because they are still comparatively few and individual speakers are many. Mass media provide a focal point for audience attention: Most people still pay much more attention to the relatively small number of traditional mass media speakers than they do to almost any particular website. That should not be surprising, for two reasons. First, traditional mass media have a head start in achieving a sizeable and stable audience because culture has been organized around them for so long. Second, the large number of speakers on the Internet dilutes audience share and fragments audience attention for any single website, depriving the vast majority of Internet speakers of mass audiences 
of the same size as the traditional mass media have enjoyed.

Therefore, although the Internet allows people to shape public opinion by routing around traditional mass media, the latter still play a crucial role in setting agendas because they still provide the lion's share of news and information to most people. Mass media remain dominant sources of entertainment, and are likely to be so for the foreseeable future. Because of economies of scale in production costs, mass media can also provide much more impressive and entertaining content than most individuals can.

The second strategy for dealing with mass media responds to this fact. It is the strategy of glomming on. To "glom on" means to appropriate and use something as a platform for innovation. "Glomming on" as a strategy means appropriating things from mass media, commenting on them, criticizing them, and above all, producing and constructing things with them: using them as building blocks or raw materials for innovation and commentary.

The word "appropriate" means to make something one's property. It is sometimes defined as making something one's exclusive property, as in appropriating a common benefit. But the glomming on characteristic of the digital age is precisely the opposite-it is nonexclusive appropriation. One appropriates something for one's own use, but others are free to appropriate it as well. This is especially the case with information goods, which are nonrivalrous and can be copied repeatedly at minimal cost.

Glomming on, then, is nonexclusive appropriation of media content for the purpose of commentary, annotation, and innovation. Here are four examples. The first is the use and development of weblogs, or blogs. Blogs grab quotes and information from other sources, including the websites run by mass media like the New York Times and the Washington Post, and use them as launching pads for commentary. Although a few blogs do original reporting, most of the blogosphere is devoted to commentary. ${ }^{13}$ A second example is the website Television Without Pity, run by a group of Canadian and American viewers. ${ }^{14}$ The site offers detailed scene-by-scene accounts of popular television shows in North America, laced with humorous and often biting commentary. Television Without Pity has grabbed the attention of television companies, which are eager to know how their shows are being received by their audiences. ${ }^{15}$ The strategy of glomming on allows at least some television viewers to talk

13 For a list of some of the most popular blogs, see The Truth Laid Bear's Blogosphere Ecosystem, at http://www.truthlaidbear.com/ecosystem.php (last visited Nov. 17, 2003).

14 See http://www.televisionwithoutpity.com (last visited Oct. 27, 2003).

15 Marshall Sella, The Remote Controllers, N.Y. TiMES, Oct. 20, 2002, (Magazine), at 70 (noting that "[i]t is now standard Hollywood practice for executive producers ... to scurry into Web groups moments after an episode is shown on the East Coast," hoping to discover what core viewers like and dislike). 
back to television producers. Fan fiction sites, which are devoted to the creation of stories about particular movies, books, and television shows, are a third example of glomming on. ${ }^{16}$ The Phantom Edit, which I mentioned earlier, is a fourth example of glomming on; it uses a traditional mass media product as an artistic platform for innovation.

Glomming onto the work of others has always existed. It is a standard form of cultural transmission and evolution. The digital revolution enhances opportunities for glomming on to the work of traditional mass media and distributing these innovations and commentary worldwide. The point is not that more glomming on is occurring, although that may be the case, but that more people are able to glom on with greater effect. In theory, at least, digital technology allows glomming on to be broadcast as widely as the media product itself. People used to talk about last night's television programs at the water cooler the next morning; now they can publish their thoughts and distribute them to a global and anonymous audience. People have long written stories about their favorite literary characters, created parodies of familiar stories and songs, and gossiped about their favorite artists. These cultural appropriations were commonplace but moved in relatively constricted circles. They existed everywhere but were not distributed everywhere. All this has changed. The very technologies that make transmission and distribution of digital information relatively costless have made glomming on a force to be reckoned with.

What I have called glomming on-the creative and opportunistic use of trademarks, cultural icons, and bits of media products to create, innovate, reedit, alter, and form pastiches and collage-is a standard technique of speech in the digital world. Glomming on is cultural bricolage using cultural materials that lay to hand. Precisely because of the astounding success of mass media in capturing the public imagination during the twentieth century, the products of mass media, now everywhere present, are central features of everyday life and thought. Mass media products-popular movies, popular music, trademarks, commercial slogans, and commercial iconography-have become the common reference points of popular culture. Hence, it is not surprising that they

16 For examples of fan fiction, see generally http://www.fanfiction.net (last visited July 10, 2003). On the clash between fan fiction and copyright law, see Rebecca Tushnet, Legal Fictions: Copyright, Fan Fiction, and a New Common Law, 17 LOY. L.A. ENT. L.J. 651 (1997); Ariana Eunjung Cha, Harry Potter and the Copyright Lawyer, WASH. POST, June 18, 2003, at A1; Tracy Mayor, Taking Liberties with Harry Potter, BostON GLOBE, June 29, 2003, (Magazine), at 14. The practice predates the Internet, see HENRY JENKIns, TEXTUAL POACHERS: TELEVISION FANS \& PARTICIPATORY CUltuRE 152-62 (1992), but the Internet has helped spur the formation of new communities of fan fiction writers, whose collective efforts have drawn the attention (and occasionally the ire) of television producers. 
have become the raw materials of the bricolage that characterizes the Internet.

Indeed, as they were originally developed, significant aspects of the Internet and digital technology facilitate glomming on. I have already mentioned the creation of common standards for encoding digital content. HTML and its successors also encourage glomming on, because they facilitate copying of source material and allow documents to point to each other. This, in turn, allows people to move seamlessly between documents and blurs the lines between them. To be sure, these features of the digital revolution need not remain untouched: As I shall now describe, businesses have tried to erect technological and legal barriers to glomming on. My point, however, is that what gives rise to these reactions by businesses are the characteristics of digital media that facilitate the cheap and widespread appropriation, manipulation, distribution, and exchange of digital information. Those very characteristics lead to attempts to undermine, limit, and cabin the facility that digital media provide.

Indeed, routing around and glomming on are not merely specific responses to mass media; they are basic characteristics of Internet speech generally. Unless the Internet's architecture has been specifically modified to prevent it, ${ }^{17}$ it is usually possible to route around any existing channel or site of discourse and start a conversation elsewhere. Similarly, unless there are technological devices put in place to avoid it, the Internet lends itself to the nonexclusive appropriation of existing content and its subsequent modification, annotation, and parody.

III

\section{THE SOCIAL CONTRAdictions OF THE Digital REVOLUTION}

Digital technology lowers the costs of distribution and production of content, both locally and worldwide. It makes it easier for people to innovate using existing information and copy and distribute what they produce to others. It makes it possible for more and more people to participate in the creation and distribution of new forms of public discourse, new forms of art, and new expressions of creativity.

The very same features of the digital age that empower ordinary individuals-low costs of distribution and ease of copying and transformation-empower businesses as well. Because it is easier and cheaper to copy and distribute media products worldwide, the digital age opens new markets for media products in digital formats, like compact

17 This is the major concern of LAWRENCE LESSIG, CODE AND OTHER LAWS OF CYBERSPACE (1999) [hereinafter LESSIG, CODE AND OTHER LAWS OF CYBERSPACE], and

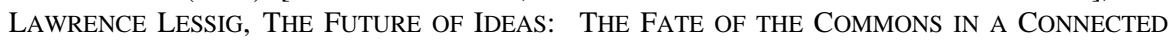
WORLD (2001) [hereinafter LESSIG, THE FUTURE OF IDEAS]. 
discs, DVDs, and streaming media.

The digital revolution, after all, is an economic revolution as well as a technological one. Because more types of media and information products can be sold to more people in more places, media products and, more generally, information itself, become increasingly important sources of wealth. In the same fashion, the infrastructure necessary to communicate and distribute information widely becomes an important source of wealth. As happened in the first age of industrialization, businesses discover economies of scale in the creation and distribution of information and media products. They become larger and more powerful; media and information industries become increasingly concentrated.

So the digital age produces two crucial trends: the democratization of digital content and the increasing importance of digital content as a source of wealth and economic power. These trends quickly come into conflict. That conflict, and its consequences for freedom of speech, is the central problem of the digital age.

The irony is this: The very same features of the digital age that empower ordinary individuals also lead businesses continually to expand markets for intellectual property and digital content. Yet as businesses do so, they must deal with features of the digital age that empower consumers and give them new abilities to copy, distribute, and manipulate digital content. Businesses wish to use the new technologies to deliver more and more content to more and more consumers, providing ever new services, ever new opportunities to purchase, and ever new forms of customization. But the technologies that allow the penetration and expansion of markets also allow consumers to route around existing media and glom on to digital content. $^{18}$

18 The basic conflict between centralized control of information production and distribution and routing around and glomming on that I have identified here has many different aspects. Yochai Benkler views the conflict in terms of contrasting methods of information production-a conflict between, on the one hand, an industrial model of protection that produces mass culture prepackaged for consumption, and, on the other, various models of nonproprietary and peer production. Yochai Benkler, Through the Looking Glass: Alice and the Constitutional Foundations of the Public Domain, 66 LAW AND CONTEMP. PROBS. 173, 181 (2003) [hereinafter Benkler, The Public Domain]; see also Yochai Benkler, From Consumers to Users: Shifting the Deeper Structures of Regulation Toward Sustainable Commons and User Access, 52 FED. ComM. L.J. 561, 562 (2000). The same technologies that allow the industrialization of the goods of the mind also make possible new forms of peer production and collaboration. See J.M. Balkin, What Is a Postmodern Constitutionalism, 90 MICH. L. REV. 1966, 1974, 1983 (1992) (defining postmodern era as era of industrialization of products of mind); see also Yochai Benkler, Coase's Penguin, or, Linux and The Nature of the Firm, 112 YALE L.J. 369, 375-90 (2002) (describing rise of collaborative methods for commons-based peer production). The struggle between these models of production, which is waged both in politics and in law, will determine the "institutional ecology" of information production in the next century. Benkler, The Public Domain, supra, at 181. 
It is obvious that businesses are worried about digital piracy-and, more generally, forms of digital appropriation-made possible by digital technologies. That is why conflicts between freedom of speech and intellectual property have come to the forefront of concern. But businesses are also concerned about the ability of consumers to alter or even refuse the conditions under which digital content is delivered and offered. Businesses would like to offer goods and services under conditions that encourage consumers to buy them. They want to facilitate advertising that supports their ventures. They want consumers to experience digital products in ways that will encourage consumption and increase profits, and they want to structure the digital environment accordingly. But digital technologies allow consumers the ability to route around these conditions. Thus, the conflict produced by the digital age is not simply a conflict about copying and piracy. It is also a conflict about control.

In a sense, this conflict was inevitable: Once intellectual property, information exchange, and media products become important sources of wealth, it is only natural that businesses will seek to maintain their profits through increasingly aggressive forms of legal and technological control. Thus, at the very moment when ordinary people are empowered to use digital technologies to speak, to create, to participate in the creation of culture, and to distribute their ideas and innovations around the world, businesses are working as hard as possible to limit and shut down forms of participation and innovation that are inconsistent with their economic interests.

We face, in other words, what Marx would have called a contradiction in social relations produced by technological innovation. ${ }^{19}$ By "contradiction," I don't mean a logical contradiction, but rather an important and pervasive social conflict brought about by technological change, a conflict that gets fought out in culture, in politics, and, perhaps equally importantly, in law. The social contradiction of the digital age is that the new information technologies simultaneously create new forms of freedom and cultural participation on the one hand, and, on the other hand, new opportunities for profits and property accumulation that can only be achieved through shutting down or circumscribing the exercise of that freedom and participation.

The social conflict produced by technological change is both a conflict of interests and a conflict of values. It produces opposed ideas of what freedom of speech means. The social contradictions of the digital age lead to opposing views about the scope and purposes of the free speech principle. This conflict appears in a number of different areas. Here I will

19 Karl Marx, A Contribution to the Critique of Political Economy, in THE MARX-EngELS READER 4, 4-5 (Robert C. Tucker ed., 1978). 
mention only two of them: intellectual property and telecommunications policy.

\section{A. Intellectual Property}

The first example is the growing tension between intellectual property and freedom of speech. That conflict has always existed, but new digital technologies have made it more salient and important. ${ }^{20}$ In hindsight, the conflict between intellectual property and freedom of speech is obvious: The whole point of intellectual property law is to bestow monopoly rights in certain forms of expression, subject to safety valves like fair use and limited times. In fact, in the United States one can even get injunctive relief against prospective copyright infringement, which flies directly in the face of the basic presumption against prior restraints on speech. ${ }^{21}$

In the past, the conflict was often avoided through benign neglect. People engaged in technical violations of intellectual property rights all the time, but their activities were not widespread and distribution was relatively limited. It didn't matter much to IP owners if a few people wrote fan fiction on their typewriters, made jokes about trademarked elements in casual conversation or in limited geographic areas, or made the occasional copy of a record on their cassette tape recorder. However, once digital content could be produced and distributed at relatively low cost and broadcast around the world, owners of intellectual property became much more worried about digital copying and trademark infringement on a massive scale, even as they became increasingly interested in exploiting derivative rights in works they already owned.

Digital content produced by isolated individuals now competes more easily with existing media products, and more easily undermines or tarnishes existing trademarks. Conversely, lower costs of distribution of digital content encourage businesses to promote their rights ever more aggressively because they can expand into new geographical markets and achieve greater market penetration. Technological change exacerbates a tension that was always present but remained dormant until low-cost methods of distribution arrived on the scene. Indeed, the digital revolution

20 On the emerging conflict between freedom of speech and intellectual property, see Yochai Benkler, Constitutional Bounds of Database Protection: The Role of Judicial Review in the Creation and Definition of Private Rights in Information, 15 BERKELEY TECH. L.J. 535, 587-600 (2000) (suggesting conflict between free speech rights and database protection); Yochai Benkler, Free as the Air to Common Use: First Amendment Constraints on Enclosure of the Public Domain, 74 N.Y.U. L. REV. 354, 393-401, 412-14 (1999) (arguing that given emerging methods of production of digital information, copyright promotes neither diversity of information nor free expression).

21 See generally Mark Lemley \& Eugene Volokh, Freedom of Speech and Injunctions in Intellectual Property Cases, 48 DUKE L.J. 147 (1998). 
is merely the latest episode in a much longer series of technological innovations that have led to the current conflict between freedom of speech and intellectual property rights. Throughout the twentieth century, mass media have become increasingly pervasive in cultural life. Print media spread more widely through technological innovation. The motion picture industry took off in the early part of the twentieth century, followed by radio, television, cable, and satellite broadcasting. All of these technologies changed how widely and cheaply one could distribute content. Each of them, in their own way, lowered distribution costs, even if they also raised the costs of content creation.

As these forms of mass media became increasingly pervasive parts of our life, the industries that create content-Hollywood, the publishing industry, and the advertising industry to name only three examples-began to push for increased protections of intellectual property rights. The reason is simple. Being able to distribute media products to more and more people justifies greater and greater investments in content creation, including, among other things, the assembly of vast teams of people to create movies, television shows, advertising campaigns, and the like. To recoup these costs, producers sought to squeeze as much profit as they could out of their media products, and one way to do that was to make their rights more valuable by pushing aggressively for additional legal protections.

Thus, during the twentieth century intellectual property rights have expanded both horizontally and vertically. ${ }^{22}$ Examples of horizontal expansion include increasing the scope of derivative rights that apply to a work at a particular point in time- the right to plot, characters, sequels, design features, orchestration, and so forth. Other examples are the development of process patents and the creation of trademark dilution law. Intellectual property rights have also expanded vertically, as the length of copyright terms has been repeatedly extended forward, and previous works have been retroactively given extensions to keep them in parity with newer works. A recent example in the United States is the Sonny Bono Copyright Term Extension Act of 1998, ${ }^{23}$ named after the former pop singer and Congressman. It extended copyrights in the United States from the life of the author plus 50 years to life plus 70 years; it also extended copyright terms to 95 years after publication for works created by corporate or anonymous authors (or 120 years after creation, whichever is shorter).

Media companies, however, have not limited themselves to legal devices. They have also attempted to use technology to protect their interests in intellectual property. An increasingly important form of

22 For a summary of the expansion in copyright law, particularly since 1970, see Neil Netanel, Locating Copyright in the First Amendment Skein, 54 STAN. L. REV. 1, 18-26 (2001).

23 Pub. L. No. 105-298, 112 Stat. 2827 (1998) (codified at 17 U.S.C. § 302 (2000)). 
intellectual property protection involves digital rights management schemes, technological devices that prevent copying of and control access to digital content. The Digital Millennium Copyright Act of $1998^{24}$ created a new species of legal rights, sometimes called "paracopyright," that make it unlawful to circumvent these technological devices or distribute circumvention devices to others. Although digital rights management is often justified as a means of preventing unauthorized copying, it actually goes much further. It is part of a general strategy of control over access to digital content, including digital content that has been purchased by the end user. ${ }^{25}$ Digital rights management schemes, for example, can make digital content unreadable after a certain number of uses; they can control the geographical places where content can be viewed; they can require that content be viewed in a particular order; they can keep viewers from skipping through commercials; and so on. Paracopyright creates legal rights against consumers and others who wish to modify or route around these forms of technological control. Once again we see how technological innovation produces social conflict: Because digital technologies make it easier to manipulate digital content in ever new ways, both businesses and consumers want increased control over how digital content is experienced.

Matters have come to a head as copying and modification of digital content have become widespread, and media companies have sought in increasingly aggressive ways to protect their existing rights and expand them further. The problem is that these legal and technological strategies are seriously curtailing freedom of expression. Not surprisingly, media companies have generally resisted the idea that freedom of speech limits the expansion of intellectual property rights. Nevertheless, at the same time that media corporations have resisted free speech objections to the expansion of intellectual property rights, they have avidly pushed for constitutional limits on telecommunications regulation on the ground that these regulations violate their own First Amendment rights.

\section{B. Telecommunications Policy}

This brings us to the second great battleground over freedom of speech: telecommunications policy. Mass media communication delivers content through some medium of transmission, whether it be spectrum, networks, telephone wires, or cables. Technologies of distribution are the "pipes” through which content travels. The key question in the digital age is who will control these "pipes."

24 Pub. L. No. 105-304, 112 Stat. 2860 (1998) (codified at 17 U.S.C. §1201 (2000)).

25 See generally LESSIG, THE FUTURE OF IDEAS, supra note 17, at 180-217; Niva ElkinKoren, It's All About Control: Rethinking Copyright in the New Information Landscape, in THE COMMODIFICATION OF INFORMATION 79 (Niva Elkin-Koren \& Neil W. Netanel eds., 2002). 
Historically, telecommunications policy in the United States has developed through several different models. Telephone companies have been viewed as conduits for the speech of others, exercising no independent editorial function. They are regarded as common carriers required to provide access to all. Broadcasters, cable companies, and satellite companies, by contrast, have been treated as hybrid enterprises. Because they provide programming and exercise editorial judgment, they have been treated as speakers with free speech rights. However, because they control key communications networks that are not freely available to all, ${ }^{26}$ they have also been subject to structural public-interest regulation. Broadcasters were at one point required to cover public issues and cover both sides of these issues fairly; they are still required to provide equal time to political candidates and to sell advertising time to federal candidates for office; cable companies have been required to make room for public, educational and government channels, to carry signals from spectrum broadcasters, and to provide cable access to low-income areas; satellite companies have been required to set aside space for educational purposes, and so on. ${ }^{27}$

The digital revolution has undermined one of the traditional justifications for structural regulation of the mass media-scarcity of bandwidth. Cable can accommodate hundreds of channels, as can satellite broadcasting. The number of speakers on the Internet seems limitless. Broadcast media now compete with cable, satellite, and the Internet for viewer attention. In theory, at least, digital technologies offer everyone the potential to become broadcasters.

Telecommunications companies have pointed to these changes as

26 Cf. Turner Broad. v. FCC (Turner I), 512 U.S. 622, 656 (1994) (arguing that monopoly power and cable architecture create bottlenecks and exclude others from speaking); Red Lion Broad. Co. v. FCC, 395 U.S. 367, 388-392, 392 (1969) ("There is no sanctuary in the First Amendment for unlimited private censorship operating in a medium not open to all.”).

27 See 47 U.S.C. § 312(a)(7) (2000) (requiring broadcasters to "allow reasonable access to or ... permit purchase of reasonable amounts of time" to "legally qualified candidate[s] for Federal elective office”); 47 U.S.C. § 315(a) (2000) (establishing “equal opportunities” rule requiring broadcasters who permit one candidate to "use" station to permit candidate's opponents to "use" station as well); 47 U.S.C. § 315(b) (2000) (requiring broadcasters to sell time at lowest unit charge to political candidates); 47 U.S.C. § 531(b) (2000) (authorizing franchise authorities to require cable companies to set aside space for public access, educational and government channels); 47 U.S.C. § 532(b)(1) (2000) (establishing “leased access” provisions which require cable operators to set aside channel capacity for use by commercial programmers unaffiliated with cable franchise operator); 47 U.S.C. § 541(a)(3) (2000) (requiring assurances in awarding cable franchises that cable access "is not denied to any group of potential residential cable subscribers because of the income of the residents of the local area in which such group resides"); 47 U.S.C. § 335(b)(1) (2000) (requiring direct broadcast satellite operators to set aside portion of "channel capacity, equal to not less than 4 percent nor more than 7 percent, exclusively for noncommercial programming of an educational or informational nature”); Red Lion, 395 U.S. at 373-75 (describing fairness doctrine). 
reasons to loosen or eliminate structural regulations of broadcast, cable, satellite, and Internet access. Businesses have argued that must-carry requirements for cable, open access requirements for broadband companies, limitations on how many media outlets a single business entity can own, and other structural and public interest obligations interfere with media companies' rights to convey the content they wish to as large an audience as possible. They have argued that these regulations, and others like them, violate their First Amendment rights as speakers and editors, and courts in the United States have increasingly begun to agree with them. ${ }^{28}$

Implicit in these arguments is a controversial capitalist theory of freedom of speech. The theory is controversial not because it accepts capitalism as a basic economic ordering principle, but because it subordinates freedom of expression to the protection and defense of capital accumulation in the information economy. The capitalist theory identifies the right to free speech with ownership of distribution networks for digital content. Although distribution networks are "public" in the sense that lots of different people use them and rely on them for communication, their hardware and software are privately owned. Hence, businesses argue, regulation of the distribution network is a regulation of the freedom of speech of the network owner, because the network owner "speaks" through its decisions about which content to favor and disfavor. Must-carry rules interfere with the editorial judgment of cable companies; open access requirements interfere with the programming choices of broadband companies; restrictions on the amount and geographical scope of media ownership interfere with the ability of media companies to send their content to as many people as possible.

The capitalist theory is controversial precisely because telecommunication enterprises are hybrids of content providers and conduits for the speech of others. This is especially true for broadband, cable, and satellite transmission. Recent telecommunications mergers have further exacerbated this hybridization by forming a small number of large, vertically integrated media conglomerates with interests in broadcast media, cable, satellite, book publishing, movie production, telephone and

28 See, e.g., Time Warner Entm’t Co. v. FCC, 240 F.3d 1126, 1136, 1139 (D.C. Cir. 2001) (invalidating FCC's limits on vertical and horizontal integration of cable carriers); Comcast Cablevision, Inc. v. Broward County, 124 F. Supp. 2d 685, 694 (S.D. Fla. 2000) (holding that open access requirements for broadband cable violate First Amendment rights of cable system owners); see also U.S. West, Inc. v. United States, 48 F.3d 1092, 1095 (9th Cir. 1994) (striking down ban on telephone companies also selling video content to the public), vacated as moot, 516 U.S. 1155 (1996); Chesapeake \& Potomac Tel. Co. v. United States, 42 F.3d 181, 202 (4th Cir. 1994) (same), vacated as moot, 516 U.S. 415 (1996). The last two cases were held moot by the Supreme Court in light of the Telecommunications Act of 1996, Pub. L. No. 104-104, 110 Stat. 56 (codified in scattered sections of 42 U.S.C. (2000)), which repealed the statutory ban on crossownership. 
Internet services.

The argument that structural regulation of telecommunications networks restricts the First Amendment rights of telecommunications companies ties the right to speak ever more closely to ownership of capital. Arguing by analogy to print media, the capitalist theory of free speech identifies the right to produce and control digital content with ownership of a communications network. Nevertheless, conflating the right to speak with the right to control a communication network is problematic for two reasons. First, because they are conduits and networks, digital communications networks are designed to provide access to multiple voices. However, under the capitalist theory, these conduits exist primarily to promote the speech of the owner of the conduit, just as newspapers exist to promote the speech of the newspaper's owner. The second problem follows from the first: Content providers who also act as conduits have incentives to favor their content over the content of others. For example, cable companies may be tempted to favor streaming media and digital music coming from the company's content providers and advertising partners, while slowing down or refusing content coming from competitors, or, for that matter, from subscribers who want to be their own broadcasters. ${ }^{29}$ Broadband companies may seek to provide "walled gardens" or "managed content areas" which limit consumer access to that of the company's proprietary network and its approved content partners. ${ }^{30}$ Broadband companies may attempt to control the end user's Internet experience by creating what Cisco Systems has called "captive portals," which, in the company's own words, give a cable system owner "the ability to advertise services, build its brand, and own the user experience." 31 The purpose of these innovations is to guide the end user into a continuous series of offers to consume goods and services from which the Internet access provider will glean profits. Through skillful control of the distribution network, access providers can determine who gets to see what

29 See LESSIG, THE FUTURE OF IDEAS, supra note 17, at 156-58 (quoting Jerome Saltzer, "Open Access" is Just the Tip of the Iceberg (Oct. 22, 1999), at http://web.mit.edu/Saltzer/www/publications/openaccess.html (last visited Oct. 20, 2003) (offering examples of gatekeeping by cable networks)).

30 See Hernan Galperin \& Francois Bar, The Regulation of Interactive Television in the United States and the European Union, 55 FED. COMM. L.J. 61, 62-64, 69-72 (2002) (discussing strategy of walled gardens in interactive television services); Daniel L. Rubinfeld \& Hal J. Singer, Open Access to Broadband Networks: A Case Study of the AOL/Time Warner Merger, 16 BERKELEY TECH. L.J. 631, 656 (2001) (noting dangers of conduit discrimination as well as content discrimination).

31 Data Sheet, Cisco 6400 Service Selection Gateway, at http://www.cisco.com/warp/public/cc/pd/as/6400/prodlit/c6510_ds.htm (last visited Oct. 20, 2003); see also Jeffrey A. Chester, Web Behind Walls, TECH. REV., June 2001, at 94, 94, available at http://www.democraticmedia.org/resources/articles/webbehindwalls.html (last visited Oct. 20, 2003). 
programming and under what terms. The goal is not simple ideological censorship but diversion of end users into ever new consumption possibilities. Access providers seek to cocoon their customers, offering continuous promotion of brands and shopping possibilities while the end user surfs the Internet.

Here we can see a second aspect of the social conflict brought about by technological innovation. New telecommunications networks allow ordinary people to communicate with vast numbers of fellow human beings, routing around existing media gatekeepers and offering competing content. People are no longer simply consumers of prepackaged content from mass media companies that are controlled by a limited number of speakers. Instead, people can use the new telecommunications networks to become active participants in the production of public culture. But the very same technologies that offer these possibilities also offer media companies ever new ways to advertise, sell products, and push their favored content. Thus, just as in the case of intellectual property, businesses that control telecommunications networks will seek to limit forms of participation and cultural innovation that are inconsistent with their economic interests. Once again, the goal is not necessarily censorship of unpopular ideas but rather diversion and co-optation of audience attention. Businesses want to direct the Internet user toward increased consumption of their own goods and services as well as the products of their advertising partners. Recognizing that there is money to be made in advertising, sales, and delivery of content, telecommunications companies do not want to be pure conduits for the speech of others, and they do not want too much content competition from their customers. Instead, they want to use the architecture of the Internet to nudge their customers into planned communities of consumerist experience, to shelter end users into a world that combines everyday activities of communication seamlessly with consumption and entertainment. In some respects, businesses seek to push consumers back into their pre-Internet roles as relatively passive recipients of mass media content. In other respects, however, they openly encourage interactivity, but interactivity on their terms - the sort of interactivity that facilitates or encourages the purchase of goods and services.

Another way of seeing the social "contradiction" created by the Internet is through the concept of "public" space. Is the Internet a private space or a public space? Digital communications networks are held in private hands, increasingly by large media conglomerates who also hold interests in digital content production and who wish to sell their own goods and services and advertise the goods and services of others. From their perspective, the "publicness" of digital communications networks is merely a side effect of the use of private property by private actors. Because digital communications networks are privately owned, those who own them 
have the right to structure entry to and use of the network by other private actors. Rather than vindicating free speech values, regulating digital communications networks violates the free speech rights of telecommunications companies.

On the other hand, digital communications networks are "public" in the sense that the public uses them as a space for general interaction. The information superhighway is a public highway used by the public for public communication, debate, gossip, and every possible form of exchange of information. Digital communications networks are also "public" in the sense that their value as networks arises from public participation that produces network effects: Communications networks are valuable to individuals because the public in general uses them, and the larger share of the public that uses the network, the more valuable the network becomes. In other words, a key source of value of the communications network is its publicness, the fact that its inhabitants and its users are the public at large. Because digital communications networks serve a public function and because they gain their value from public participation, the argument goes, digital communications networks should be regulated to serve the public interest and to allow members of the public to use them as public spaces for communication, cultural innovation and public participation. Without such regulation, powerful private interests will trample on free speech values in the relentless pursuit of profits.

IV

\section{FREEDOM OF SPEECH IN THE SECOND GILDED AGE}

Let me summarize the argument so far: Technological innovations in the digital age have produced conflicts about the meaning of free expression in two different locations. The first is the scope of intellectual property; the second is the regulation of telecommunications networks. The conflict over freedom of speech looks quite different in these two areas. In intellectual property, media corporations have pushed for evergreater protection of intellectual property through both legal and technological means. They have rejected complaints that ever-expanding intellectual property rights and digital rights management schemes inhibit freedom of expression because they eliminate fair use and shrink the public domain. In telecommunications regulation, by contrast, media corporations have aggressively pushed for expansion of free speech rights, arguing that the right to free speech includes the right to control communications networks. Invoking a property-based theory of free expression, they have rejected arguments that public regulation is necessary to keep conduits open and freely available to a wide variety of speakers.

Thus, in the digital age, media corporations have interpreted the free 
speech principle broadly to combat regulation of digital networks and narrowly in order to protect and expand their intellectual property rights. What is more, courts increasingly have begun to agree with these two positions. ${ }^{32}$

These positions seem inconsistent on their face. In fact, they are not. They reflect a more basic agenda: It is not the promotion and protection of freedom of speech per se, but the promotion and protection of the property rights of media corporations. Both intellectual property and freedom of speech have been reconceptualized to defend capital investments by media corporations. Intellectual property rights, paracopyright, and digital rights management are justified as necessary to protect property rights and maintain a fair return on investment. Freedom of speech increasingly is being reinterpreted as the right to be free from economic regulation of digital communications networks. This is part of a larger trend of the past twenty-five years, in which businesses have also used the First Amendment to attack restrictions on advertising and campaign finance. ${ }^{33}$ We are just beginning to see the First Amendment invoked to defend the accumulation and sale of consumer data against government regulation. ${ }^{34}$ One of the most important developments of the past quarter century is the emergence of the First Amendment and the free speech principle as anti-regulatory tools for corporate counsel. ${ }^{35}$ At the same time, intellectual property, paracopyright, and digital rights management are being invoked not only to restrict cultural experimentation and innovation, but to control how ordinary individuals experience the Internet. ${ }^{36}$ What these positions have in common is not a libertarian impulse, but a desire for greater control over

32 See Eldred v. Reno, 239 F.3d 372, 380 (D.C. Cir. 2000), aff'd sub nom. Eldred v. Ashcroft, 537 U.S. 186, 222 (2003) (holding that First Amendment poses no obstacle to Congressional extension of copyright terms that shrink scope of public domain, even when extension is retroactive); Universal City Studios, Inc. v. Reimerdes, 111 F. Supp. 2d 294 (S.D.N.Y. 2000) (upholding constitutionality of application of Digital Millenium Copyright Act to DeCSS and enjoining linking to websites from which DeCSS might be obtained), aff'd sub nom. Universal City Studios, Inc. v. Corley, 273 F.3d 429 (2001); supra note 26 (citing additional cases).

33 See J.M. Balkin, Some Realism About Pluralism: Legal Realist Approaches to the First Amendment, 1990 DUKE L.J. 375, 375-87 (noting “ideological drift” of free speech principle to protect propertied and corporate interests).

34 See, e.g., U.S. West, Inc. v. FCC, 182 F.3d 1224, 1235, 1239 (10th Cir. 1999) (invalidating, on First Amendment grounds, FCC regulations protecting privacy and sale of telephone customers' personal information). On some of the problems faced in squaring consumer privacy with a libertarian conception of freedom of speech, see Eugene Volokh, Freedom of Speech and Information Privacy: The Troubling Implications of a Right to Stop People from Speaking About You, 52 STAN. L. REV. 1049 (2000).

35 Balkin, supra note 33, at 384; Mark Tushnet, Corporations and Free Speech, in THE Politics of LAW: A Progressive CritiQue 253 (David Kairys ed., 1982); Mark Tushnet, An Essay on Rights, 62 TEX. L. REV. 1363, 1386-92 (1984).

36 LESSIG, THE FUTURE OF IDEAS, supra note 17, at 196-202; Elkin-Koren, supra note 25, at 84-85, 88-98. 
how individuals will be permitted to use digital networks and digital content; which is to say, it is a desire for control over the very technologies that had created new possibilities for individual freedom and cultural innovation in the digital age.

In a sense, this development was inevitable. In the world in which we live, intellectual property and control of digital communications networks are increasingly important sources of wealth. The defense of those forms of wealth must find a legal manifestation. Intellectual property and freedom of speech serve these functions admirably.

We have been through this before. Jacksonian and abolitionist ideas before the Civil War produced a constitutional vision of free labor and free contract. This constitutional vision celebrated the right of ordinary individuals to own their labor. Laissez-faire was defended as a means of keeping government from giving special benefits to the wealthy. As America industrialized, corporations took up these Jacksonian and abolitionist ideas and reinterpreted them, transforming them into defenses of corporate property rights and constitutional attacks on government regulation of employment conditions. Courts issued labor injunctions against union organizing on the grounds that allowing workers to form unions undermined the value of employer investments in capital. ${ }^{37}$ Courts turned the ideology of free labor into a constitutional principle of liberty of contract that prevented governments from regulating wages and working conditions. ${ }^{38}$

In what Clinton Rossiter called the "Great Train Robbery of Intellectual History," ${ }^{39}$ laissez-faire conservatives appropriated the words and symbols of early nineteenth-century liberalism-liberty, opportunity, progress, and individualism - and gave them an economic reinterpretation that served corporate interests. ${ }^{40}$ They massaged and refitted the existing rhetoric of free labor and the right of ordinary citizens to pursue a calling into a sophisticated defense of corporate power and privilege that smashed labor unions, protected sweatshops, and eviscerated health and safety

37 Cf. Truax v. Corrigan, 257 U.S. 312, 328 (1921) (holding that attempt to ban labor injunctions violated property rights of business owner).

38 A substantial literature has developed explaining how Gilded Age ideas of freedom of contract were created out of Jacksonian and free labor ideals. See, e.g., Michael Les Benedict, Laissez-Faire and Liberty: A Re-Evaluation of the Meaning and Origins of Laissez-Faire Constitutionalism, 3 LAW \& HIsT. REV. 293 (1985); William E. Forbath, The Ambiguities of Free Labor: Labor and the Law in the Gilded Age, 1985 WIS. L. REV. 767, 798-99 (1985); Charles W. McCurdy, The Roots of "Liberty of Contract" Reconsidered: Major Premises in the Law of Employment, 1867-1937, 1984 YEARBOOK OF THE SUPREME COURT HISTORICAL SOCIETY 20. Revisions of this view have suggested that other influences were also at work, see Stephen A. Siegel, The Revision Thickens, 20 LAW \& HIST. REV. 631 (2002), but have not undermined the basic point that corporate interests made ample use of these rhetorical resources.

39 Clinton Rossiter, CONSERVATISM IN AMERICA 128 (2d ed. rev. 1962).

40 Id. at 128-62; see Balkin, supra note 33, at 383-87. 
laws. ${ }^{41}$ By the turn of the twentieth century, the best legal minds that money could buy had reshaped the liberal rights rhetoric of the 1830s into a powerful conservative defense of property that they claimed was the rightful heir to the best American traditions of individualism and personal freedom.

A similar transvaluation of values is overtaking the free speech principle today. ${ }^{42}$ The right to speak has been recast as a right to be free from business regulation. Copyright is slowly being converted to property simpliciter with virtually perpetual terms; trademark and patent have steadily grown in scope; and database protection, already extant in the European Union, ${ }^{43}$ is on the horizon in the United States. ${ }^{44}$ Indeed, in some respects, digital rights management and paracopyright offer copyrighted works even greater protection than ordinary property receives. ${ }^{45}$ Intellectual property, which was originally viewed as a limited government monopoly designed to encourage innovation, has been transformed into a bulwark against innovation, facilitating control over digital content and limiting the speech of others.

We are living through a Second Gilded Age, which, like the first Gilded Age, comes complete with its own reconstruction of the meaning of liberty and property. ${ }^{46}$ Freedom of speech is becoming a generalized right

41 See generally ARNOld M. PAUl, CONSERVATIVE CRISIS AND THE RUle OF LAW: ATTITUDES OF BAR AND BENCH, 1887-1895 (1960); BENJAMIN R. TWISS, LAWYERS AND THE CONSTITUTION: HOW LAISSEZ FAIRE CAME TO THE SUPREME COURT (1942).

42 The comparison between the ideological drift of the principles of freedom of contract and freedom of speech is explored in Balkin, supra note 33, at 375-87, and J.M. Balkin, Ideological Drift and the Struggle over Meaning, 25 CONN. L. REV. 869 (1993).

43 Council Directive 96/9, 1996 O.J. (L 77/20) (providing for legal protection of databases which, "by reason of the selection or arrangements of their contents, constitute[] the author's own intellectual creation”).

44 For a discussion of recent attempts, see Dov S. Greenbaum, The Database Debate: In Support of an Inequitable Solution, 13 ALB. L.J. SCI. \& TECH. 431, 468-78 (2003).

45 Cf. Randal C. Picker, From Edison to the Broadcast Flag: Mechanisms of Consent and Refusal and the Propertization of Copyright, 70 U. CHI. L. REv. 281, 293-96 (2003) (noting that digital rights management permits perfection of continuing control over use of intellectual property in digital content even after media product has been purchased).

46 Or, in Julie Cohen's memorable phrase, we are entering the era of "Lochner in Cyberspace." Julie Cohen, Lochner in Cyberspace: The New Economic Orthodoxy of "Rights Management,” 97 MicH. L. REV. 462 (1998).

Paul Schwartz and William Treanor argue, by contrast, that calls for constitutional limitations on the expansion of intellectual property are the best analogy to the laissez-faire constitutional conservatism of the Gilded Age; they compare arguments for constitutional protection of the public domain to Lochner v. New York, 198 U.S. 45 (1905). Paul M. Schwartz \& William Michael Treanor, Eldred and Lochner: Copyright Term Extension and Intellectual Property as Constitutional Property, 112 YALE L.J. 2331, 2334-35, 2394-95, 2411 (2003). They fail to consider the social and economic context in which the debate over laissez-faire conservatism occurred. In effect, Schwartz and Treanor argue that small-scale artists, software programmers, Internet end users, and consumers who seek a robust public domain are the functional equivalent of the Robber Barons and concentrated economic interests of the Gilded 
against economic regulation of the information industries. Property is becoming the right of the information industries to control how ordinary people use digital content. We can no more capitulate to the Second Gilded Age's construction of these ideas than to the constructions offered in the first Gilded Age. We must offer a critical alternative to this construction, much as progressive thinkers did a century ago.

\section{$\mathrm{V}$}

\section{THE PROGRESSIVIST THEORY AND ITS LiMITATIONS}

So far, I have explained how digital technologies have changed the social conditions in which speech is produced, and I have described the way that the information industries have attempted to reinterpret freedom of speech. These reinterpretations reflect the interests of businesses attempting to secure certain privileges in a changing economy. They are by no means necessary or inevitable, and indeed, I think that they are in many respects mistaken.

There is a better way to understand the free speech principle in the digital era. The alternative is a theory of freedom of speech based on the idea of a democratic culture. In order to explain this alternative, I would

Age, while today's media corporations like Microsoft, Disney and Viacom are the functional equivalent of immigrant laborers in sweatshops at the turn of the century.

Because they focus exclusively on arguments about the scope of the Copyright Clause, and pay no attention to telecommunications law, Schwartz and Treanor do not recognize that the free speech principle is the key battleground for the legal protection of capital in the information economy. Opposition to the Copyright Term Extension Act turned precisely on the fact that the political economy of the information age blurs distinctions between regulations of speech and regulations of business practices in media corporations, and that ever-expanding property rights in patent, trademark, and copyright adversely affect freedom of expression. See Brief of Jack M. Balkin et al. as Amici Curiae in Support of the Petition at 15-21, Eldred v. Ashcroft, 537 U.S. 186 (2003) (No. 01-618), available at 2002 WL 1041899.

Much more troubling than the Court's conclusions about the Copyright Clause in Eldred is its cavalier dismissal of the important free speech interests in limited copyright terms. See Eldred, 537 U.S. at 218-22. From this perspective, Eldred most closely resembles not Lochner v. New York, but the early twentieth-century cases Schenck v. United States, 249 U.S. 47 (1919), Abrams v. United States, 250 U.S. 616 (1919), and Gitlow v. New York, 268 U.S. 652 (1925), in which the Court rejected free speech claims and exercised judicial restraint. The danger is that an unrestrained legislature beholden to media interests will continually ramp up intellectual property protections at the expense of the free speech interests of others.

Schwartz and Treanor note the argument that the expansion of intellectual property arises from rent-seeking by media corporations that have corrupted the political process. Schwartz \& Treanor, supra, at 2406. However, failing to recognize the First Amendment interests involved, they assume that the only issue is the adjustment of property rights between competing stakeholders. They argue that the defects of political process, even if serious, cannot justify heightened judicial review, see United States v. Carolene Prods. Co., 304 U.S. 144, 152 n.4 (1938), because the theory of process protection should not apply to ordinary economic and social legislation but only to "the representation of minorities." Schwartz \& Treanor, supra, at 2407. Perhaps tellingly, they omit the Carolene Products Court's argument that the theory of process protection is equally concerned with securing freedom of speech. 
like to retrace my steps and think about how free speech theory dealt with the last great technological change, the rise of broadcast media.

Probably the most important theoretical approach to freedom of speech in the twentieth century has argued that freedom of speech is valuable because it preserves and promotes democracy and democratic selfgovernment. The notion that there is an important connection between freedom of speech and democracy is hardly new-people have understood the connection for as long as democracies have been around. But the twentieth century produced a special emphasis on that connection, and during the course of the twentieth century, many thinkers claimed that the very purpose of freedom of speech was not so much to promote individual autonomy or personal fulfillment as to promote democratic deliberation about public issues. We can find the beginnings of this idea in Progressive Era thinkers in the first two decades of the twentieth century. ${ }^{47}$ The most famous statement is by the philosopher of education Alexander Meiklejohn, ${ }^{48}$ and his approach has greatly influenced later theorists. ${ }^{49}$

As a shorthand, I will call the democracy-based approach of Meiklejohn and his followers the "republican" or "progressivist" approach. That is because a focus on democratic deliberation rather than individual autonomy is characteristic of republican political theory, and it is also characteristic of much thinking in the Progressive Era in the United

47 See Mark A. Graber, Transforming Free SpeEch: The Ambiguous Legacy of CIVIL LIBERTARIANISM 92-93, 122-26 (1991) (noting rise of democratic conception in Progressive period and discussing democratic elements in Zechariah Chafee, Jr.'s theory of free expression); David M. Rabban, Free Speech in Progressive Social Thought, 74 TEX. L. REv. 951, 954-88 (1996) (discussing free speech theories of early twentieth-century progressive thinkers, including John Dewey and Herbert Croly).

48 See generally Alexander MeiKlejohn, Political Freedom: The Constitutional Powers of the People (1960) [hereinafter Meiklejohn, Political Freedom]; Alexander Meiklejohn, The First Amendment is an Absolute, 1961 SuP. CT. REV. 245 [hereinafter Meiklejohn, First Amendment].

49 See, e.g., OWEN M. FISS, THE IRONY OF FREE SPEECH (1996) [hereinafter FISS, THE IRONY of Free Speech]; Cass R. Sunstein, Democracy and the Problem of Free Speech (1993); Owen M. Fiss, Free Speech and Social Structure, 71 IowA L. REV. 1405 (1986) [hereinafter Fiss, Free Speech and Social Structure]; Owen M. Fiss, Why the State?, 100 HARV. L. REV. 781 (1987) [hereinafter Fiss, Why the State?]; Harry Kalven, The New York Times Case: A Note on "The Central Meaning of the First Amendment," 1964 SUP. CT. REV. 191. Fiss well describes the centrality of this theory in twentieth-century legal thought:

The theory that animates this protection [of the speaker's autonomy], and that inspired Kalven, and before him Meiklejohn, and that now dominates the field, casts the underlying purpose of the first amendment in social or political terms: The purpose of free speech is not individual self-actualization, but rather the preservation of democracy, and the right of a people, as a people, to decide what kind of life it wishes to live. Autonomy is protected not because of its intrinsic value, as a Kantian might insist, but rather as a means or instrument of collective self-determination. We allow people to speak so others can vote. Speech allows people to vote intelligently and freely, aware of all the options and in possession of all the relevant information.

Fiss, Free Speech and Social Structure, supra, at 1409-10. 
States. ${ }^{50}$ Progressivism is a sensibility, an attitude about what democracy is and what wise government can do. The progressive has faith in government's ability to promote the public interest through rational deliberation, works to structure government and public decisionmaking to promote deliberation and consensus about important public policy issues, worships expertise, and views popular attitudes and popular culture with suspicion because they tend to be emotional, parochial, irrational, untutored, and in need of channeling, refinement, and education. ${ }^{51}$

I think it is no accident that the progressivist/republican approach to free speech arose in the twentieth century, for this was also the century of mass media. People who endorse democratic theories of free speech understand that although mass media can greatly benefit democracy, there is also a serious potential conflict between mass media and democratic selfgovernance. The reason is that mass media are held by a comparatively few people, and their ownership gives this relatively small group enormous power to shape public discourse and public debate. The danger is that they will use their dominant position in three equally worrisome ways.

The first worry is that the people who control mass media will skew coverage of public issues to promote views that they support. In a world where ownership of mass media is concentrated in the hands of a relatively few very wealthy individuals and corporate conglomerates, the agendas and concerns of the wealthy will prevail, constricting discussion of serious issues and serious alternatives to the status quo. As a result, people will get disinformation or a skewed picture of the world around them, and this will be harmful for democracy.

The second worry is that mass media will omit important information, issues, and positions that the public should take into account. As a result, people will be exposed to only a limited set of issues to deliberate about, and to only a limited number of ways of thinking about and dealing with this limited set of issues.

The third worry is that mass media will reduce the quality of public discourse in the drive for higher ratings and the advertising revenues and other profits that come with them. Mass media will oversimplify and dumb down discussions of public issues, substitute sensationalism and amusement for deliberation about public questions, and transform news and politics into forms of entertainment and spectacle. The endless drive for advertising revenues and profits tends to drive out serious discourse and

50 On the connections between democratic free speech theory and republicanism, see BAKER, supra note 9, at 126-27, 138-43, 152-53, 170-76. On the connection to the thought of the Progressive Era, see GRABER, supra note 47, at 75-121; Balkin, supra note 2, at 1947-48, 195658; Rabban, supra note 47.

51 Balkin, supra note 2, at 1947-48, 1956-58. 
replaces it with mind-numbing entertainment. This demobilizes the public, leaving them less and less interested in focusing on important public issues of the day.

For these three reasons, democracy-based theorists of free speech in the twentieth century have argued that government must regulate the mass media in a number of different ways: (1) by restricting and preventing media concentration; (2) by imposing public-interest obligations that require the broadcast media to include programming that covers public issues and covers them fairly; and (3) by requiring the broadcast media to grant access to a more diverse and wide-ranging group of speakers in order to expand the agenda of public discussion.

The progressivist/republican approach is an important counterweight to a market-oriented approach to freedom of speech that ties speech rights closely to ownership of property. I mentioned this approach in my discussion of telecommunications policy in the digital age, but of course, the argument that people who own telecommunications media should be free of government regulation predates the Internet. Indeed, the new market-based arguments are simply logical continuations of arguments for deregulation of the broadcast media that have been going on for many years. ${ }^{52}$ The Internet has simply given media corporations a new justification for using the free speech principle as an anti-regulatory tool: Because people do not need access to the mass media to speak, governments have lost their greatest justification for mass media regulation.

However, we cannot expect that the Internet will adequately compensate for any loss in media diversity that might come from deregulation, elimination of public interest obligations, and increased media concentration. First, market concentration in mass media is not unrelated to market concentration in cable and broadband ownership. Many of the same companies that have gobbled up an increasingly large share of mass media markets also have control over cable companies and broadband companies. As we have seen, these companies have interests in eliminating competition and controlling the Internet experience of end users. So increased media concentration may actually exacerbate or dovetail with loss of end-user autonomy on the Internet. Second, the quality and diversity of information that flows over the Internet is inevitably shaped by the quality and diversity of information available in broadcast media and cable, because that is where a very large number of people still get most of their news and information. If more traditional

52 See, e.g., Mark S. Fowler \& David L. Brenner, A Marketplace Approach to Broadcast Regulation, 60 TEX. L. REV. 207 (1982) (arguing for repeal of most forms of broadcast regulation). 
mass media provide disinformation, constrict agendas of public discussion, displace discussion of public issues, and demobilize audiences, Internet speech can only partially compensate. We cannot view the Internet as a complete substitute for mass media. Instead, Internet speech is layered on top of the forms of public discourse and discussion that cable and broadcast media provide. This follows from my argument that speech on the Internet routes around and gloms onto the products of the mass media. The mass media remain a central substrate on which Internet speech builds.

Nevertheless, the Internet does make a difference to freedom of speech. The digital age exposes weaknesses and limitations in democracybased theories of free speech, just not the ones with which the capitalist approach is concerned.

Progressivist and republican approaches arose in response to the challenge to democracy posed by mass media. And their limitations arise from the same set of concerns. The progressivist/republican approach is limited in three important respects. First, it emphasizes political questions and deliberation about public issues over other forms of speech. It tends to value other kinds of speech to the extent that they contribute to public discussion of political questions rather than for their own sake. Second, for the same reason, the progressivist/republican approach tends to downplay the importance of popular culture, too often seeing it as ill-informed and a distraction from serious issues. Third, because its paradigmatic concern is broadcast media held by a relatively small number of people, who may misuse their power to control the public agenda or demobilize the citizenry, the progressivist/republican approach tends to downplay the centrality of liberty and personal autonomy to freedom of speech. ${ }^{53}$ It focuses instead on equality and on the production of a suitable agenda for public discussion. In Meiklejohn's famous phrase, the point of freedom of speech is not that everyone shall speak, but that "everything worth saying shall be said.” 54

The progressivist/republican argument that we should not tie the right of free speech too closely to the right of private property remains valid, particularly in an age of increasing media concentration. That is because the liberty of speech and the liberties involved in property ownership are

53 Meiklejohn was perhaps most overt about this, arguing that the First Amendment "has no concern about the 'needs of many men to express their opinions'” but rather is concerned with "the common needs of all the members of the body politic." MEIKLEJOHN, POLITICAL FREEDOM, supra note 48, at 55; see also id. at 56-57, 61 (criticizing Zechariah Chafee, Jr. for being "misled by his inclusion of an individual interest within the scope of the First Amendment," and Justice Oliver Wendell Holmes for his "excessive individualism"). Owen Fiss, likewise, has emphasized that the First Amendment's concern with autonomy is primarily instrumental: "Autonomy may be protected, but only when it enriches public debate." Fiss, Why the State?, supra note 49, at 786.

54 MeiKLejohn, Political FreEdom, supra note 48, at 26. 
two different kinds of freedom. Although property rights often assist free expression - think of the right to use the software and the computer that one owns-they can also undermine it, as suggested by the examples of content discrimination in telecommunications networks and the use of digital rights management to control the end user's experience.

Nevertheless, the paradigm case that motivates the progressivist agenda - the case of few speakers broadcasting to a largely inactive mass audience-no longer describes the world we live in. Even if, as I have argued, the new digital technologies do not displace mass media, they exist alongside it and build on top of it. Digital technologies give lots of people, more than ever before, a chance to participate in the creation and development of public culture. Technological changes in how speech is transmitted, and in who gets to participate in that transmission, change the focus of free speech theory.

VI

THE IDEA OF A DEMOCRATIC CULTURE

Let me begin by pointing to five characteristics of Internet speech that I believe are exemplary of freedom of speech generally. These characteristics are hardly new to the Internet; rather, my point is that the Internet makes them particularly salient. That salience, I shall argue, reshapes our conception of the free speech principle.

First, speech on the Internet ranges over every possible subject and mode of expression, including the serious, the frivolous, the gossipy, the erotic, the scatological, and the profound. The Internet reflects popular tastes, popular culture, and popular enthusiasms.

Second, the Internet, taken as a whole, is full of innovation. The tremendous growth of the Internet in a relatively short period of time shows how enormously creative ordinary people can be if given the chance to express themselves. And it demonstrates what ordinary people can do when they are allowed to be active producers rather than passive recipients of their cultural world.

Third, much of the source of that creativity is the ability to build on something else. This is particularly true of the World Wide Web. As originally conceived, the very structure of HTML code encourages copying, imitation, and linking. The continual innovation and transformation we see in digital media stems directly from their ability to use the old to make the new. Digital media allow lots of people to comment, absorb, appropriate, and innovate-to add a wrinkle here, a criticism there. Internet speech continually develops through linkage, collage, annotation, mixture, and through what I have called routing around and glomming on. Internet speech, like all speech, appropriates and 
transforms. It imitates, copies, builds upon and mixes.

Fourth, Internet speech is participatory and interactive. People don't merely watch (or listen to) the Internet as if it were television or radio. Rather, they surf through it, they program on it, they publish to it, they write comments and continually add things to it. Internet speech is a social activity that involves exchange, give and take. The roles of reader and writer, producer and consumer of information are blurred and often effectively merge.

Fifth, and finally, because Internet speech is a social activity, a matter of interactivity, of give and take, it is not surprising that Internet speech creates new communities, cultures and subcultures. In this way, it exemplifies an important general feature of freedom of speech: Freedom of speech allows us, each of us, to participate in the growth and development of the cultures and subcultures that, in turn, help constitute us as individuals. Freedom of speech is part of an interactive cycle of social exchange, social participation, and self-formation. We speak and we listen, we send out and we take in. As we do this, we change, we grow, we become something other than we were before, and we make something new out of what existed before.

To sum up, the Internet makes particularly salient five facts about free speech: Speech ranges over a wide variety of subjects, including not only politics but also popular culture. The speech of ordinary people is full of innovation and creativity. That creativity comes from building on what has come before. Speech is participatory and interactive as opposed to mere receipt of information. It merges the activities of reading and writing, of production and consumption. Finally, speech involves cultural participation and self-formation. The Internet reminds us how central and important these features are to speech generally. It reveals to us in a new way what has always been the case.

And this brings me to a central point: The populist nature of freedom of speech, its creativity, its interactivity, its importance for community and self-formation, all suggest that a theory of freedom of speech centered around government and democratic deliberation about public issues is far too limited. The free speech principle has always been about something larger than democracy in the narrow sense of voting and elections, something larger even than democracy in the sense of public deliberation about issues of public concern. If free speech is about democracy, it is about democracy in the widest possible sense, not merely at the level of governance, or at the level of deliberation, but at the level of culture. The Internet teaches us that the free speech principle is about, and always has been about, the promotion and development of a democratic culture.

Democracy is far more than a set of procedures for resolving disputes. It is a feature of social life and a form of social organization. Democratic 
ideals require a further commitment to democratic forms of social structure and social organization, a commitment to social as well as political equality. ${ }^{55}$ And the forces of democratization operate not only through regular elections, but through changes in institutions, practices, customs, mannerisms, speech, and dress. A "democratic" culture, then, means much more than democracy as a form of self-governance. It means democracy as a form of social life in which unjust barriers of rank and privilege are dissolved, and in which ordinary people gain a greater say over the institutions and practices that shape them and their futures.

What makes a culture democratic, then, is not democratic governance but democratic participation. A democratic culture includes the institutions of representative democracy, but it also exists beyond them, and, indeed undergirds them. A democratic culture is the culture of a democratized society; a democratic culture is a participatory culture.

If the purpose of freedom of speech is to realize a democratic culture, why is democratic cultural participation important? First, culture is a source of the self. Human beings are made out of culture. A democratic culture is valuable because it gives ordinary people a fair opportunity to participate in the creation and evolution of the processes of meaningmaking that shape them and become part of them; a democratic culture is valuable because it gives ordinary people a say in the progress and development of the cultural forces that in turn produce them.

Second, participation in culture has a constitutive or performative value: When people are creative, when they make new things out of old things, when they become producers of their culture, they exercise and perform their freedom and become the sort of people who are free. That freedom is something more than just choosing which cultural products to purchase and consume; the freedom to create is an active engagement with the world. ${ }^{56}$

55 On the social features of democracy implicit in the idea of a democratic culture, see J.M. Balkin, The Constitution of Status, 106 YALE L.J. 2313, 2314 (1997); J.M. Balkin, The Declaration and the Promise of a Democratic Culture, 4 WIDENER L. SYMP. J. 167 (1999).

56 Legal scholars influenced by John Fiske have argued that intellectual property law should also serve the goals of promoting popular participation in culture, or what Fiske called "semiotic democracy." See, e.g., William W. Fisher III, Property and Contract on the Internet, 73 CHI.KENT L. REV. 1203, 1217 (1998) ("In an attractive society, all persons would be able to participate in the process of meaning-making. Instead of being merely passive consumers of cultural artifacts produced by others, they would be producers, helping to shape the world of ideas and symbols in which they live."); see also Kenneth Karst, Local Discourse and the Social Issues, 12 CARDOZO STUD. L. \& LIT. 1, 27 (2000) (defining cultural democracy as "the broadest possible participation in the cultural processes that define and redefine the sort of society we shall be"). Larry Lessig's recent call for "free culture," see LESSIG, THE FUTURE OF IDEAS, supra note 17, at 9-10, also has important connections to the principles of semiotic democracy and democratic culture, as does David Lange's notion of free appropriation as a right of citizenship exercised in the public domain, see David Lange, Reimagining the Public Domain, 66 LAW \& CONTEMP. 
By "culture” I mean the collective processes of meaning-making in a society. The realm of culture, however, is much broader than the concern of the First Amendment or the free speech principle. Armaments and shampoo are part of culture; so too are murder and robbery. And all of these things can affect people's lives and shape who they are. The realm of culture for purposes of the free speech principle is a subset of what anthropologists study as forms of culture. It refers to a set of historically contingent and historically produced social practices and media that human beings employ to exchange ideas and share opinions. ${ }^{57}$ These are the methods, practices, and technologies through which dialogue occurs and public opinion is formed. For example, today people generally regard art as a social practice for the exchange of ideas, and they regard motion pictures as a medium of expression..$^{58}$ These practices and media of social

PROBS. 463, 475-83 (2003).

Important examples of this trend in intellectual property scholarship include Rosemary J. Coombe, Author/izing the Celebrity: Publicity Rights, Postmodern Politics, and Unauthorized Genders, 10 CARDOZO ARTS \& ENT. L.J. 365 (1992); Rosemary J. Coombe, Objects of Property and Subjects of Politics: Intellectual Property Laws and Democratic Dialogue, 69 TEX. L. ReV. 1853 (1991); Rosemary J. Coombe, Publicity Rights and Political Aspiration: Mass Culture, Gender Identity, and Democracy, 26 NEW ENG. L. REv. 1221 (1992); Rochelle Cooper Dreyfuss, Expressive Genericity: Trademarks as Language in the Pepsi Generation, 65 NOTRE DAME L. REV. 397 (1990); Niva Elkin-Koren, Cyberlaw and Social Change: A Democratic Approach to Copyright Law in Cyberspace, 14 CARDOZO ARTS \& ENT. L.J. 215, 272-73 (1996); David Lange, At Play in the Fields of the Word: Copyright and the Construction of Authorship in the Post-Literate Millennium, 55 LAW \& CONTEMP. PROBS. 139 (1992); Jessica Litman, The Public Domain, 39 EMORY L.J. 965 (1990); Madow, supra note 2; William Fisher, Theories of Intellectual Property, http://www.law.harvard.edu/Academic_Affairs/coursepages/tfisher/iptheory.html (last visited Dec. 3, 2003).

Other scholars have sought to connect the proper scope of copyright, fair use and the public domain to the promotion of democracy in the sense of public discussion of public issues. See Neil Weinstock Netanel, Copyright and a Democratic Civil Society, 106 YALE L.J. 283, 347-65 (1996) [hereinafter Netanel, Copyright and a Democratic Civil Society] (arguing that copyright promotes democracy by funding independent sectors of creativity); Neil Weinstock Netanel, Market Hierarchy and Copyright in Our System of Free Expression, 53 VAND. L. REV. 1879 (2000). This strand of intellectual property scholarship is somewhat closer to the republican or progressivist model; it emphasizes the importance of democratic public discourse and views popular culture as valuable to the extent that it contributes to a democratic civil society. See Netanel, Copyright and a Democratic Civil Society, supra, at 351 n.310.

57 For a helpful discussion, see Robert Post, Recuperating First Amendment Doctrine, 47 StAN. L. REV. 1249, 1253-55 (1995). Post argues that social practices and media for the communication of ideas are central to the formation of public opinion. Robert Post, Reconciling Theory and Doctrine in First Amendment Jurisprudence, 88 CAL. L. REV. 2353, 2367-69 (2000); Post, Recuperating First Amendment Doctrine, supra, at 1275-77.

58 It was not always thus. See Post, Recuperating First Amendment Doctrine, supra note 57, at 1252-53 (discussing Mutual Film Corp. v. Industrial Comm., 236 U.S. 230, $243-45$ (1915), in which Supreme Court originally held that motion pictures were not "organs of public opinion”). By 1952, the Supreme Court had come around, stating that "it cannot be doubted that motion pictures are a significant medium for the communication of ideas.” Joseph Burstyn, Inc. v. Wilson, 343 U.S. 495, 501 (1952). The difference between the Court's statements in 1915 and 
communication construct the realm that we regard as "speech" for purposes of the free speech principle. ${ }^{59}$ We cannot give an exhaustive list of these practices and media precisely because the social conventions and technologies that define them are always evolving; even so, it seems clear enough that the Internet and other digital technologies are media for the communication of ideas, and an increasingly important way for people to express their ideas and form their opinions. ${ }^{60}$ They are central—and I would say crucial—media for the realization of a democratic culture.

Culture has always been produced through popular participation. Digital technology simply makes this aspect of democratic life more obvious, more salient. Radio and television are technologies of mass cultural reception, where a few speakers can reach audiences of indefinite size. But the Internet is a technology of mass cultural participation in which audiences can give as well as receive, broadcast as well as absorb, create and contribute as well as consume. Digital technology makes the values of a democratic culture salient to us because it offers the technological possibility of widespread cultural participation.

What is the difference between grounding freedom of speech on the promotion of democracy and grounding it on the promotion of a democratic culture? What is at stake in the move to culture?

There are three important differences, I think, and each stems from the weaknesses of the progressivist/republican model: They concern the status of nonpolitical expression, the role of popular culture, and the importance of individual participation and individual liberty.

\section{A. Nonpolitical Expression}

A serious difficulty with the progressivist/republican model has always been that a wide variety of activities, of which art and social commentary are only the most salient examples, have always fit poorly into a democratic theory of free expression. Lots of speech is not overtly political. Nevertheless, it gets protected under the progressivist/republican

1952 reflects important changes in American society to which the Court's First Amendment doctrines eventually responded. The scope of the free speech principle always grows out of a normatively inflected recognition of sociological realities.

59 The free speech principle also applies to regulations of conduct that do not involve a generally recognized medium for the communication of ideas when the government regulates conduct because it disagrees with or desires to suppress the ideas it believes the conduct expresses. See United States v. O’Brien, 391 U.S. 367, 377-78 (1968) (holding that reasons for regulation of conduct must be unrelated to suppression of free expression). Thus, when government effectively treats conduct as a medium for the communication of ideas and punishes it on that basis, the free speech principle is also implicated.

60 See, e.g., Reno v. ACLU, 521 U.S. 844, 850 (1997) ("The Internet is 'a unique and wholly new medium of worldwide human communication." (quoting ACLU v. Reno, 929 F. Supp. 824, 844 (E.D. Pa. 1996))). 
model because it is useful for political discussion, because it may become enmeshed in political controversies (and thus threatened or suppressed for political reasons), or because it is very hard to draw lines separating what is political from what is not. ${ }^{61}$ In like fashion, lots of activities cannot easily be classified as deliberation-like singing, shouting, protesting, gossiping, making fun of people, or just annoying them or getting them angry. Nevertheless, these activities are protected because we can think of them as raw materials for further democratic deliberation or because we cannot easily draw lines separating them from the social practice of deliberation. ${ }^{62}$ In both cases, then, we have kinds of speech that are at the periphery rather than the core; we protect them in aid of something more central and precious. In short, the progressivist vision sees democratic deliberation about public issues at the core of constitutional concern and other subjects and other forms of expression as peripheral or supplementary.

I have never been satisfied with this approach. I think something is missing here, and the notion of democratic culture helps us understand why. The point of democracy, as its name implies, is to put power in the hands of the people, to give ordinary people some measure of control over the forces that shape their lives and some degree of say about how the world around them develops. But law and governance are only parts of this world. Culture is an even larger part, and in some ways it has an even more capacious role in structuring our lives. The various processes of communication and cultural exchange are the sources of the self and its development over time. Our ideas, our habits, our thoughts, our very selves are produced through constant communication and exchange with others. ${ }^{63}$ The influence is reciprocal: Through this continuous

61 Meiklejohn himself argued that works of art were protected speech because they promoted knowledge, sharpened intelligence, and developed sensitivity to human values, thus helping people to make political decisions. Meiklejohn, First Amendment, supra note 48, at 255-57. Other scholars have recognized that not all artistic expression equally promotes democratic selfgovernment. See, e.g., SunSTEIN, supra note 49, at 153-59 (1993) (suggesting that nonpolitical art should be relegated to lower tier of First Amendment protection). And of course Robert Bork, who also had a democracy-based theory of the First Amendment, famously argued that art should receive no First Amendment protection if it was not political speech. Robert H. Bork, Neutral Principles and Some First Amendment Problems, 47 IND. L.J. 1, 26-28 (1971).

Owen Fiss believes, to the contrary, that art, particularly unorthodox art and art underappreciated by market forces, furthers the goals of collective self-determination and democratic deliberation. He argues that government programs like the National Endowment for the Arts (NEA) that subsidize art should look to art that is concerned with issues on the public agenda or that should be on the public agenda of discussion and comment. Thus, government subsidy of art should be designed to promote discussion of important public issues. FISS, THE IRONY OF FREE SPEECH, supra note 49, at 40-45.

62 Cf. Owen M. Fiss, The Unruly Character of Politics, 29 MCGEORGE L. REV. 1, 2-7 (1997) (noting limitations of Meiklejohnian metaphor of town meeting as applied to confrontational politics).

63 On the formation of self through cultural transmission, see JACK M. BALKIN, CULTURAL 
communication and exchange, we shape culture and are shaped by it in turn. We absorb it, we inhabit it, we make it new. We send it out into the world, we make it part of us.

Culture is more than governance, more than politics, more than law. And if democracy is giving power to the people, then true democracy means allowing people not only to have a say about who represents them in a legislature, or what laws are passed, but also to have a say about the shape and growth of the culture that they live in and that is inevitably part of them. Power to the people-democracy —in its broadest, thickest sense, must include our relationship not simply to the state but to culture as a whole, to the processes of meaning-making that constitute us as individuals. Those processes of meaning-making include both the ability to distribute those meanings and the ability to receive them. ${ }^{64}$

Culture is an essential ingredient of the self, and so freedom of speech means participation in the forces of culture that shape the self. We participate in the growth and development of culture through interaction, through communicating to others and receiving ideas from others. Cultural democracy is memetic democracy, the continuous distribution, circulation, and exchange of bits of culture from mind to mind. ${ }^{65}$ This vision of culture is not democratic because people are voting on what is in their culture. It is democratic because they get to participate in the meaning-making processes that form and reproduce culture. They do this through communicating with and interacting with others. Moreover, democratic culture is not democratic because people are participating in processes of deliberation about governance, or even public issues. Rather it is

SOFTWARE: A THEORY OF IDEOLOGY 269-85 (1998).

64 As Julie Cohen reminds us, digital technologies tend to blur the boundaries between production and reception, speaking and reading, or even between viewing and copying. See Julie E. Cohen, A Right to Read Anonymously: A Closer Look at "Copyright Management" in Cyberspace, 28 CONN. L. REV. 981, 1004-09 (1996); see also Rubenfeld, supra note 5, at 34-36 (arguing that theories of freedom of expression based in autonomy and self expression do not sufficiently account for First Amendment right to read as well as to express one's self).

65 Memetics is an evolutionary theory that attempts to explain the development of culture through the transmission of bits of culture, or memes, which replicate themselves in human minds. The term "meme" was coined by the zoologist Richard Dawkins. See RICHARD DAWKINS, THE SELFISH GENE 189-94 (1977). Memetic theory often tends to undermine agency and selfhood, see, e.g., SUSAN BLACKMORE, THE MEME MACHINE (1999), and thus would seem an odd choice for a theory of self expression. But memetics can also be employed to explain concepts central to agency and selfhood like freedom, see DANIEL C. DENNETT, FREEDOM EVOLVES 175-92, 266 (2003), or the growth of human belief systems and human innovation, see BALKIN, supra note 63, at 42-97, 173-75.

The idea of memetic democracy emphasizes the deep connections between self and agency on the one hand, and cultural evolution and the shaping of the self through cultural exchange on the other. Memetic democracy means that everyone gets to participate in the distribution and dissemination of memes, which are the building blocks of the cultural software that constitutes individuals as individuals. 
democratic because it is participation in the creation and shaping of culture, which is, at the same time, participation in the growth and development of the self.

\section{B. Popular Culture}

The second basic problem with the work of Meiklejohn and his heirs has been its relative neglect and suspicion of popular culture. Popular culture is often seen as mass culture controlled by corporations, which demobilizes the citizenry; as sensationalism or dumbed-down speech, which adds little of importance to democratic deliberation; or as mere entertainment, which distracts people from serious discussion of public issues. ${ }^{66}$ But from the perspective of democratic culture, popular culture and entertainment should not be merely peripheral or a distraction. They should be a central part of what freedom of speech is about.

In an age of unidirectional mass media, popular culture was, to a very large extent, mass culture — a set of commodities manufactured and sent out to be consumed by a mass audience. But the Internet allows mass culture to be appropriated by ordinary citizens and become, more than ever before, a truly popular culture, because it allows what I have called routing around and glomming on. ${ }^{67}$

66 See, e.g., LeE C. Bollinger, IMAGES OF A FrEE PRESS 138-41 (1991) (contrasting burdens of education for civic life with pleasantness of entertainment); SUNSTEIN, supra note 49, at 84-91 (decrying "low quality” programming that appeals to tastes of uneducated); Fiss, Free Speech and Social Structure, supra note 49, at 1413 ("From the perspective of a free and open debate, the choice between Love Boat and Fantasy Island is trivial.”); Fiss, Why the State?, supra note 49, at 788 (contrasting reruns of "I Love Lucy" and MTV with "the information [members of the electorate] need to make free and intelligent choices about government policy, the structure of government, or the nature of society.”). Once again, this familiar progressivist theme is already present in Meiklejohn. See MeIKLEJohn, PoliticAl FrEedOM, supra note 48, at 87 (attacking commercial radio for "corrupt[ing] both our morals and our intelligence"). Even Justice Louis Brandeis fell prey to this sort of cultural elitism, which pervades his famous call for protecting the right of privacy from a particular form of speech. See Samuel Warren \& Louis Brandeis, The Right to Privacy, 4 Harv. L. REv. 193, 196 (1890) (arguing that "personal gossip," "[e]asy of comprehension [and] appealing to that weak side of human nature," "crowds the space available for matters of real interest to the community," and "destroys at once robustness of thought and delicacy of feeling").

67 In this sense the Internet simply empowers the popular appropriation and transformation of mass culture that already existed:

Much of mass culture involves programming, advertisements, architecture, and artwork produced by corporations and designed to sell products and make money. Many critiques of mass culture warn of the deleterious consequences of consumerism and mass consumption.... But a populist view [of democratic culture] also emphasizes that ordinary people are not mere passive receptors of the messages offered in advertising, television programming, and other elements of contemporary mass culture. Such assumptions are just another way of denigrating the intelligence and abilities of ordinary people. People do not uncritically absorb and assimilate the images they see on the television screen - they process, discuss, and appropriate them. People are active interpreters and rearrangers of what they find in mass culture. They use the raw 
We can understand the controversies over intellectual property in this light. Media corporations are turning to digital rights management to avoid digital piracy. But much of what traditional mass media most fears and resents is not piracy but cultural appropriation-individual riffs on mass media digital products shared with others-and the ability of consumers to route around a controlled advertising and marketing environment. Shifting our focus from democracy to democratic culture helps us see that the problem in the digital age is not just deliberation about public issues. It is also the importance of letting ordinary people engage in appropriation and innovation rather than mere consumption; it is the value of ordinary people being able to "rip, mix, and burn," 68 to route around traditional media gatekeepers and glom onto existing media products.

In a democratic culture, we are interested in protecting not only speech about public issues, but also speech that concerns popular expression in art, as well as cultural concerns such as gossip, mores, fashions, and popular music. The progressivist/republican approach has tended to valorize high culture and high quality programming as aids to democratic deliberation (often conflating the two in the process), with "low" culture protected only as a peripheral concern. ${ }^{69}$ But if freedom of speech is concerned with the promotion of a truly democratic culture, popular culture is every bit as important as so-called high culture. ${ }^{70}$ In fact, in a democratic culture, the distinction between high culture and low culture begins to blur and the difference between them becomes increasingly difficult to maintain. High culture continually borrows from popular culture; moreover, as culture becomes increasingly democratized, the popular culture of today often turns out to be the high culture of tomorrow.

materials of mass culture to articulate and express their values. Through this process, they produce and reproduce popular culture. Balkin, supra note 2, at 1948-49 (footnotes omitted).

68 The reference is to Apple's famous commercial instructing users of its iPod to "[R]ip, mix, and burn. ... After all, it's your music.” Larry Lessig uses the slogan as a metaphor for a free culture. LESSIG, THE FUTURE OF IDEAS, supra note 17, at 9-11.

69 See Sunstein, supra note 49, at 87-91; see also Cass R. Sunstein, Television and the Public Interest, 88 CAL. L. REV. 499, 518 (2000) (arguing that goal of television regulation is to promote deliberative democracy).

70 See Balkin, supra note 2, at 1948 ("[P]opular culture is neither a debilitated version of democratic culture nor a mere diversion from the sober processes of deliberation imagined by progressivism. It is not a sideshow or distraction from democratic culture but the main event. Moreover, [a] populis[t] [approach to free expression] accepts, as progressivism does not, that popular culture-which is also democratic culture-is by nature unkempt and unruly, occasionally raucous and even vulgar. It is by turns both eloquent and mawkish, noble and embarrassing, wise and foolish, resistant to blandishments and gullible in the extreme. It is imperfect in precisely the same sense that democracy itself is imperfect.”). 


\section{Individual Participation}

A third problem with the progressivist/republican model has been its tendency to seek to manage discourse and structure public debate. ${ }^{71}$ This desire is hardly surprising: In a world dominated by mass media controlled by a relative handful of very wealthy corporations, it seems important to make sure that dissenting views get a word in edgewise, that serious issues are not driven out by the media's never-ending quest for profits, and that audiences are not stultified and demobilized by an endless stream of increasingly vapid entertainment. As a result, the progressivist model has downplayed individual liberty and instead played up the protection of democratic processes, including robust debate on public issues and the creation of an informed citizenry. Earlier, I noted Meiklejohn's famous statement that the point of freedom of speech is not that everyone shall speak, but that everything worth saying shall be said. Meiklejohn even analogized the system of free expression to a town meeting. ${ }^{72}$ The purpose of the town meeting was to shape a public agenda for discussion of serious issues; there would be time for only some people to speak. The important point was that the participants in the meeting be informed and stick to the agenda because everyone would decide what to do on the basis of the information presented. Although Meiklejohn's town meeting seems quite distant from the electronic mass media, it had many of the same features: scarcity of time, the need for a public agenda, and the importance of an informed citizenry. Hence the need for regulation was very much the same.

Democratic culture, by contrast, is not solely concerned with people's ability to be informed about a particular agenda. It is concerned with participation, interaction, and the ability of people to create, to innovate, to borrow ideas and make new ones. Meiklejohn remarked that his ideal town meeting was "self-government," not a "dialectical free-for-all." "73 That opposition may hold true for a particular form of democracy. But in a democratic culture, and especially the culture of the Internet, freedom of expression is a dialectical free-for-all, a continuous process of interactivity and innovation, in which culture and discussion move and grow in any number of different directions.

Here again a shift in focus from democracy to democratic culture

71 Robert Post has emphasized this limitation of the Meiklejohn model, arguing that the autonomy of public discourse, necessary for democratic self-government, is undermined by imposing managerial methods to cabin its scope and agendas. See generally Robert Post, Managing Deliberation: The Quandary of Democratic Dialogue, 103 ETHICS 654 (1993); Robert Post, Meiklejohn's Mistake: Individual Autonomy and the Reform of Public Discourse, 64 U. COLO. L. REV. 1109 (1993).

72 MeiKLejohn, Political FreEdom, supra note 48, at 24-27.

73 Id. at 25. 
responds to the sorts of freedoms that digital technologies make possible. Digital technologies and telecommunications networks mean that people are no longer forced into the role of mere spectators and consumers; they can be active participants, creating, commenting, and broadcasting their own ideas to a larger public. And in a world in which active participation in the creation and distribution of culture becomes possible for so many, liberty is an important good to be prized, valued, and nourished.

The progressivist/republican conception of free speech arose in the twentieth century because ordinary people were shut out of the most pervasive and important forms of speech and were reduced to the roles of spectators, consumers, and recipients. In that world, protecting the liberty of a favored few who owned the means of communication from regulation was less important than producing discussion on public issues and promoting a robust agenda of diverse and antagonistic sources so that the citizenry could be well-informed and engaged with the great public issues of the day. But new technologies make it possible for vast numbers of people to participate, innovate, and create, to route around and glom on to the traditional mass media and their products. This has increased enormously the practical liberty of the ordinary citizen to speak, and to reach a vast audience. When technology makes liberty possible, liberty once again must return to the forefront of concern. ${ }^{74}$

74 Indeed, the standard progressivist/republican arguments for regulation of broadcast, cable, and satellite can and should be rearticulated in terms of the more populist perspective of promoting democratic culture. The key point is that the United States has adopted a hybrid system: Instead of separating the functions of editor and distributor, and treating all distribution networks as common carriers like telephone companies, it has allowed a small number of editors/speakers to own powerful distribution networks not open to all in return for accepting various public service obligations and regulations. Thus the hybrid system is based on the model of a contract or a quid pro quo.

Although the hybrid system denies the vast majority of people free access to key distribution networks, it may nevertheless have been justified in the past by its economic advantages. Arguably it offers necessary incentives for broadcasters, cable companies, and owners of satellite systems to invest in, produce, and deliver a wide variety of diverse programming for viewers and listeners that will enrich public debate and public culture. Thus, it provides considerable grist for the mill of a democratic culture.

Nevertheless, a hybrid system is hardly perfect. Heavy reliance on advertising tends to create a significant mismatch between what broadcasters deliver and what viewers want, in part because advertisers seek content that appeals to the common tastes of certain valued demographic groups (whose preferences may otherwise be quite heterogenous) rather than content that crosscuts demographic groups or appeals to groups with comparatively little disposable income or comparatively unmanipulable consumption patterns. See BAKER, supra note 9, at 13, 24-26, 8891, 182-90. Advertisers will also tend to push for content that helps induce greater consumption instead of content that appeals to and fulfils other values that viewers might have. For example, viewers may value many kinds of content that are not strongly tied to shopping, purchasing, and consumption. They may value content that educates them or inspires them to change their lives, rethink their values, or make use of their creative powers. Finally, market forces also will, almost by definition, underproduce content that has high positive externalities (like educational content, or balanced and informative coverage of news) because the value of that content to society cannot 
The twentieth-century concern with speech as a method of democratic deliberation privileges the delivery of information about issues of public concern to the public, who receive this information through asymmetric and unidirectional mass media. I do not wish to deny the importance of that conception; I merely want to insist that it is only a partial conception, inadequate to deal with the features of speech that the new digital technologies bring to the foreground of our concern. The values behind freedom of speech are about production as much as reception, about creativity as much as deliberation, about the work of ordinary individuals as much as the mass media.

Freedom of speech is more than the freedom of elites and concentrated economic enterprises to funnel media products for passive reception by docile audiences. Freedom of speech is more than the choice of which media products to consume. Freedom of speech means giving everyonenot just a small number of people who own dominant modes of mass communication, but ordinary people, too-the chance to use technology to participate in their culture, to interact, to create, to build, to route around and glom on, to take from the old and produce the new, and to talk about whatever they want to talk about, whether it be politics, public issues, or popular culture.

VII

\section{DigITAL LIBERTY}

Shifting our focus from democracy to democratic culture helps us better understand the idea of freedom of speech in the digital age. Indeed, I would go even further. Digital technologies change our understanding of what liberty of speech is. They make salient features of freedom of speech that have always been present. Digital technologies offer people the liberty

be captured by market forces, and, all other things being equal, the greater the positive externalities, the more underproduction there will be. Id. at 41-62, 114-18.

The hybrid model of media regulation is not constitutionally required. Rather, it is a quid pro quo or contractual arrangement, and it is constitutional to the extent that it promotes the values of a democratic culture. To be sure, regulatory quid pro quos can violate free speech rights if they impose an unconstitutional condition on free speech. However, structural regulations of the mass media that seek to counteract the limitations of mass media markets should be constitutional if there is a clear nexus between the goals of the regulation and the purposes behind the choice of a hybrid system. To the extent that structural regulations and public interest obligations of mass media compensate for the limitations of a hybrid model, they are tied to the very justifications for issuing broadcast licenses and cable franchises in the first place: They help further the goal of promoting a rich public sphere and a vibrant, participatory, and democratic culture. If government can make a sufficiently good case that the regulations will have this effect, the regulations should not be regarded as unconstitutional conditions on a media company's First Amendment rights. Likewise, public broadcasting that supplements existing markets with content that government reasonably believes to be valuable (like children's programming) should also be constitutionally permissible. 
to participate in culture through application of existing cultural materials, the ability to appropriate and innovate using tools freely available to all. Digital technology offers a possibility, not yet fully realized (and conceivably one that will never be fully realized), of what democratic culture might be.

A democratic culture is the culture of widespread "rip[ping], mix[ing], and burn[ing]," 75 of nonexclusive appropriation, innovation, and combination. It is the culture of routing around and glomming on, the culture of annotation, innovation, and bricolage. Democratic culture is not the same thing as mass culture. It makes use of the instrumentalities of mass culture, but transforms them, individualizes them, and sends what it produces back into the cultural stream. In democratic culture, individuals are not mere consumers and recipients of mass culture but active appropriators. Culture has always had opportunities for popular participation. The Internet and digital technologies merely increase the number of opportunities for widespread distribution, their scope, and their power; and, in the process, make them more obvious to us. Digital speech places these features of liberty-and the possibility of democratic culturemore clearly and centrally before us.

What is the liberty of expression, viewed from the perspective of the ideal of democratic culture? I would say that it has four important components that have been made more salient by digital technology: (1) the right to publish, distribute to, and reach an audience; (2) the right to interact with others and exchange ideas with them, which includes the right to influence and to be influenced, to transmit culture and absorb it; (3) the right to appropriate from cultural materials that lay at hand, to innovate, annotate, combine, and then share the results with others; and (4) the right to participate in and produce culture, and thus the right to have a say in the development of the cultural and communicative forces that shape the self.

What these facets of liberty have in common is that they are not selfregarding. Communication is interaction, sharing, influencing, and being influenced in turn. Creation is not creation ex nihilo, but building on the work of others; appropriation is not exclusive appropriation but making use of tools that lay to hand that are part of a common pool of resources. Distribution is not isolated but occurs through public pathways and networks that many can travel on. Finally, development of the self is a project that one shares with others.

In short, what the Internet makes salient to us is that freedom of expression, that most individualistic of liberties, that most personal of activities, is at the very same time deeply communal, because it is interactive, because it is participatory, because it builds on the work of

75 See supra note 68. 
what others have done, and because it makes use of public networks and pathways of distribution. I do not mean by this that liberty exists merely for the purposes of the state, or that individual liberty is an illusion. Far from it. I mean precisely the opposite - that the realization of individuality, the expression of one's individual self, the promotion of one's individual dignity, comes out of and through culture, a shared feature of life. Culture is the substrate, the raw materials of individual freedom, from which individual liberty emerges and within which individual liberty operates and innovates. ${ }^{76}$

The concept of a democratic culture restores freedom to its central place in free speech theory, but in the process, offers a particular conception of what that freedom is:

Freedom is participation. Freedom is distribution. Freedom is interaction. Freedom is the ability to influence and be influenced in turn. Freedom is the ability to change others and to be changed as well. Freedom is the ability to glom on and route around. Freedom is appropriation, transformation, promulgation, subversion, the creation of the new out of the old. Freedom is mixing, fusing, separating, conflating, and uniting. Freedom is the discovery of synergies, the reshuffling of associations and connections, the combination of influences and materials.

Freedom is bricolage.

Dissent is central to this conception of free speech, for dissent is cultural as well as political. ${ }^{77}$ Just as the progressivist/republican critique has too narrow a focus on why speech is valuable, it has too limited a conception of dissent. People may disagree with what the government is doing, and they may express themselves in politics, in music, or in art. But they can also disagree with the aesthetics and mores of others, and they can dissent by borrowing from and subverting what they borrow. And just as democratic culture undergirds democracy in the narrow sense without being identical to it, cultural dissent is an important source of political dissent without being subsumed by it.

Perhaps equally important, dissent involves all of the features of liberty I have just described: interaction, appropriation, and transformation. Dissent reacts to, borrows from, and builds on what it disagrees with. Dissent, whether in culture or in politics, is not mere negation. Rather, dissent is creative and cumulative. It appropriates elements of what it objects to and uses them in the process of critique, often through subverting or parodying them. ${ }^{78}$ The nature and focus of dissent is

\footnotetext{
76 See BALKIN, supra note 63, at 17-19.

77 See Madhavi Sunder, Cultural Dissent, 54 Stan. L. Rev. 495, 498 (2001) (noting ubiquitous disputes within cultural groups about values of group and terms of membership).

78 See, e.g., Judith P. Butler, Gender Trouble: Feminism AND the SubVersion of
} 
shaped by what the dissenter disagrees with, and the form of response is shaped by the way the problem appears to the critic. Thus, dissent exists in an interactive and interdependent relationship to the object of its criticism, appropriating elements of what it rebukes in order to make its claims. Dissent makes use of the raw materials that inspire its disagreement and resistance. In this way, dissent, and responses to dissent, are not mere repudiations of what has come before, but have a cumulative effect, building on existing materials and practices, and propelling and transforming culture forward.

I have emphasized that the ability of ordinary individuals to produce their own culture is a central aspect of the liberty of free expression. What justifies this populist focus? Why shouldn't we organize telecommunications and intellectual property law to maximize the ability of large business enterprises to make large investments in cultural products (e.g., blockbuster movies) while allowing consumers to choose which ones they prefer to consume in the marketplace? Why isn't this cultural division of labor an equally good protection of freedom of speech?

One answer is that the ability to participate in culture and produce one's own meanings can offer people greater self-realization and selffulfillment than perpetually being relegated to the docile consumption of mass media products. But even if we remain agnostic on that point, being an active producer/creator is at least as good a way of living as being a passive consumer/recipient, and it is an equally important part of the liberty of expression.

Market forces are likely to underprotect the right of ordinary individuals to be active cultural producers, because media companies are likely to make more money from consumption of the media products they advertise and sell. From the standpoint of these companies, individual cultural production has no independent value except to the extent that it involves or leads to the consumption of media goods. And to the extent that active cultural participation diverts end users from greater consumption of media products, interferes with the companies' expansive definition of intellectual property rights, or challenges corporate technologies of control, it is less valuable than passive consumption; indeed it is positively harmful and must be cabined in.

One might object that media companies will invest in products and services that facilitate individual cultural appropriation and production if

IDENTITY 141-49 (1990) (noting possibilities for subversion of existing sexual roles and creation of new ones through repetition and through performance); Amy M. Adler, What's Left?, 84 CAL. L. REV. 1499, 1529-31 (1996) (describing how pornography has been appropriated for feminist purposes); Judith P. Butler, The Force of Fantasy: Feminism, Mapplethorpe, and Discursive Excess, 2 DIFFERENCES 105, 119-20 (1990) (arguing that “discursive excess” offers opportunities for subversion and parody). 
consumers want them badly enough. To some extent this is true: We have already seen the beginnings of this in multi-user online games. But individual cultural production often has high positive externalities; it provides benefits and satisfactions that are not easily captured by markets. ${ }^{79}$ So media companies may have insufficient incentives to facilitate individual cultural appropriation and production. Conversely, they will tend to over-invest in products that relegate individuals to a position of relatively passive consumers.

Choosing what products to consume is a kind of liberty, but it does not exhaust the liberty of free expression. The ability to produce, create, and innovate is just as important. These two forms of liberty are not fungible, and markets do not adequately measure the difference between them. ${ }^{80}$ To protect freedom of expression, then, we must make a space for individual cultural appropriation and production. We should not choose a form of political economy that gives greater incentives to be a passive recipient than an active creator of culture.

Democratic culture is a regulative ideal. It offers a picture of what the world could look like given the technology we now have. It offers a picture of what freedom of speech could be in a digital world. Nevertheless, digital technology does not guarantee the production of a democratic culture. As I noted previously, businesses are now using the new technologies to attempt to constrain and channel democratic participation. They are doing so both through laws and through technological solutions, including packet discrimination and digital rights management. And they are justifying these innovations through an interpretation of freedom of speech that ties speech to property rights. This capitalist conception is important both for its explanation of what freedom of speech is (freedom from business regulation) and what it is not (an enforceable limit on the expansion of intellectual property rights).

The ideal of democratic culture is important precisely as a critical perspective that allows us to criticize this emerging interpretation of free speech and intellectual property. The developing capitalist conception of freedom of speech (and its accompanying denial of free speech limitations on the growth of intellectual property) is inconsistent with the promotion of a democratic culture. The same technological changes that suggested what a democratic culture might become have produced a very different interpretation of the free speech principle that ties it ever more closely to

79 See BAKER, supra note 9, at 41-55.

80 Purchasing media products is a kind of liberty, because it involves choice. It is also a kind of creativity, because an agreement between a willing buyer and a willing seller creates wealth. But it does not exhaust the forms of choice and creativity with which freedom of speech is concerned. 
the ownership of the forms of capital characteristic of the information age-intellectual property and control over distribution networks. The idea of a democratic culture stands as a critique of this emerging property-based conception. That critique is crucial, because the architecture of the digital age and the law that governs distribution networks are up for grabs. They can develop in many different ways, and the point is to ensure that they develop in the right ways.

\section{VIII}

\section{THE JUDICIAL MODEL AND ITS LIMITATIONS}

To protect freedom of speech in the digital age, we will have to reinterpret and refashion both telecommunications policy and intellectual property law to serve the values of freedom of speech, which is to say, we will have to fashion and interpret them with the goals of a democratic culture in mind.

How is this to be done? I have argued that the digital age subtly alters our understanding of liberty of expression. I believe it also changes how that liberty might be protected.

Throughout the twentieth century, the most familiar method of protecting freedom of speech was through the judicial creation and protection of individual legal rights, and in particular, constitutional rights. Of course, when we look more closely, we will also discover many other features of public policy that promoted free speech values. They include, among other things, free public education, the creation and maintenance of public libraries, a nationwide public mail system, subsidies for postage for books and publications by nonprofit organizations, the use of common carrier models for telephony, and national telecommunications policies that attempted to lower costs and increase access to radio and television. For the most part, however, these policies have been regarded as largely peripheral to the main event - the judicial recognition and creation of doctrines that protect free speech rights from government censorship or other forms of government regulation.

Indeed, the very success of the program of expanding individual free speech rights protected by courts made it an article of faith that this was how freedom of speech should be secured-through the judicial creation and protection of individual rights of free expression enforceable against state actors. This notion has two important and distinct assumptions. First, it assumes that one protects freedom of expression through protecting individual rights of free speech, rather than through creating systems of communication and information-sharing used by lots of people that facilitate free expression. Put differently, it views the system of free expression as no more than the sum of all of the individual rights of free 
expression. Second, the model assumes that these individual rights will be created and protected primarily by courts, rather than by legislatures or administrative agencies, or, for that matter, by engineers, software designers, and technology companies.

Nevertheless, the examples I mentioned earlier-free public education, free public libraries, common carrier rules in telephony, public interest rules in telecommunications, a public mail system, government subsidies for books and nonprofit publications, and so on-do not match these assumptions. They are policies and institutions that promote a healthy and democratic system of free expression, but they are not composed of individual free speech rights. Rather, they combine lots of different private rights with various government programs and entitlements, and in the case of telecommunications regulations, they may even include requirements for technological design. Second, these features of the system of free expression are not always primarily created or protected by courts. Rather, they are created by a number of parties, including legislatures and administrative agencies.

The model of judicial protection of individual rights remains crucially important in the digital age. But it will not be able to protect freedom of speech fully. The digital age makes increasingly apparent what has always been the case- - that the system of free expression relies on something more than the sum of all individual free speech rights. It relies on a technological and regulatory infrastructure. That infrastructure is produced through government regulation, through government subsidies and entitlement programs, and through technological design. Freedom of speech is, and always has been, a cultural phenomenon as well as a legal or political one. A healthy and well-functioning system of free expression depends on technologies of communication and a public ready and able to use those technologies to participate in the growth and development of culture.

In the digital age, the technological and regulatory infrastructure that undergirds the system of free expression has become increasingly important. Elements of the system of free expression that were backgrounded in the twentieth century will become foregrounded in the twenty-first. They will be foregrounded, I argue, because the guarantee of a pure formal liberty to speak will increasingly be less valuable if technologies of communication and information storage are biased against widespread individual participation and toward the protection of property rights of media corporations. If we place too much emphasis on judicial doctrine at the expense of infrastructure, we will be left with formal guarantees of speech embedded in technologies of control that frustrate their practical exercise.

The system of free expression is produced through the synergy of (1) 
government policies that promote popular participation in technologies of communication, (2) technological designs that facilitate decentralized control and popular participation rather than hinder them, and (3) the traditional recognition and enforcement of judicially created rights against government censorship. The last of these-judicial creation and enforcement of rights of free speech against government abridgement-is the great achievement of the twentieth century. Nevertheless, I believe that in the long run it will be recognized as only one leg of a three-legged stool that supports the system of free expression. The other elements will increasingly move to the foreground of concern as it becomes clear that they are necessary to the promotion of a democratic culture.

IX

THE INFRASTRUCTURE OF FREE EXPRESSION: FROM FREE SPEECH RightS TO FREE SPEECH VALUES

As the focus shifts from an exclusive concern with judicially protected individual constitutional rights to an additional concern with infrastructure, we must also shift our concern from free speech rights narrowly considered to free speech values. Free speech rights are rights of individuals enforceable by courts. Free speech values are values that we seek to promote through legislative and administrative regulation and through technological design.

Protecting freedom of speech in the digital age means promoting a core set of values in legislation, administrative regulation, and the design of technology. What are those values? They are interactivity, broad popular participation, equality of access to information and communications technology, promotion of democratic control in technological design, and the practical ability of ordinary people to route around, glom on, and transform. Free speech values include those aspects of liberty of expression that the digital age makes most salient: popular participation, interactivity, and the encouragement and protection of cultural creativity and cultural transformation.

Both technological architectures and legal regimes of regulation must be structured to make possible full and robust participation by individuals. Free speech values must enter both into the content of laws and the design of architectures of communication. That is because the key forms of capital in the digital era-intellectual property and telecommunications networks - can serve both as conduits for increased democratic cultural participation or as chokepoints and bottlenecks, centralizing control in the hands of a relatively few persons and organizations. What form informational capital will take, how it will be used, how it will be shared or if it will be shared at all, are the crucial questions of the digital age. 
At stake in both intellectual property and telecommunications regulation is the question of democratic participation versus centralized control. This is most obvious in the context of distribution networks: The capitalist theory of free speech asserts the right of the owner of a communications network to control the flow of digital content through the network. But the capitalist theory also seeks to expand intellectual property rights so that rights holders can control the distribution, use, and transformation of media products even after these products are distributed and sold to a mass audience. The theory of free speech as democratic culture, by contrast, argues that both communications networks and intellectual property rights must facilitate broad cultural participation. Communications networks are public in nature even if their technological infrastructure is privately owned. Therefore they must grant fair access to their networks, they must not act as chokepoints or bottlenecks, and they must not unfairly discriminate against content from other sources. Intellectual property rights must also serve democratic ends: They exist to promote the spread of culture and possibilities for cultural innovation and transformation.

To make intellectual property consistent with the idea of free speech as democratic culture, there must be a robust and ever expanding public domain with generous fair use rights. Intellectual property also must not be permitted to create chokepoints or bottlenecks in the spread of knowledge and the distribution of culture.

Judicial creation and protection of individual rights is ill equipped to deal with many of the most important problems of freedom of speech in the digital era. Free speech values are often either promoted or hindered by the ways that technologies are designed and the ways that technological standards are set. Technological designs and standards can let private parties become gatekeepers and bottlenecks controlling the flow of information and the scope of permissible innovation; or, conversely, they can promote widespread participation and innovation.

Law has an important role to play here. Laws affect how technology is designed, the degree of legal protection that a certain technology will enjoy, and whether still other technologies that modify or route around existing technological forms of distribution and control will be limited or forbidden. But increasingly, these sorts of decisions will be made by legislatures and administrative agencies in consultation with private parties. Generally speaking, courts come to free speech controversies after technologies are already in place and deals between stakeholders have already been struck. Courts can construe existing statutes to protect free speech values. But in most cases they cannot easily order that particular new technologies or new standards be implemented. They cannot easily hold, for example, that a certain technological design must be adopted. 
They cannot insist that private companies refrain from using certain digital rights management technologies in return for a congressional statute that sets up a compulsory licensing scheme. Courts can remand lower court and administrative agency decisions, but they cannot easily remand technologies to their designers and ask them to make the technology more free speech friendly. Nor can they order or oversee the sort of comprehensive bargains that contemporary intellectual property regulation increasingly requires. Those tasks will fall to other actors, with courts enforcing the legal bargains that are produced consistent with free speech values.

The free speech values I have identified-participation, access, interactivity, democratic control, and the ability to route around and glom on-won't necessarily be protected and enforced through judicial creation of constitutional rights. Rather, they will be protected and enforced through the design of technological systems-code-and through legislative and administrative schemes of regulation, for example, through open access requirements or the development of compulsory license schemes in copyright law.

This transforms the study of freedom of speech to the study of the design of architectures and regulatory systems. It is no accident, I think, that many of the people who are at the forefront of the push for freedom in cyberspace are computer scientists, engineers, and software programmers, and it is no accident that lawyers who do cyberlaw spend an increasing amount of time thinking about technological and administrative solutions to civil rights issues. That is because, as I have argued, free speech values are embedded both in administrative regulations and in technological design. To protect free speech in the digital age, lawyers have to become cyberlawyers, ${ }^{81}$ not simply lawyers who study cyberlaw, but lawyers who think about how technology can best be structured and how public policies can best be achieved through wise technological design..$^{82}$

\section{CONCLUSION: RIGHTS DYNAMISM}

I return to the question I posed at the beginning of this essay: How should the theoretical justifications for freedom of speech change given the change in social conditions produced by the digital age?

We can now offer an answer to this question. Technological change presents new possibilities for freedom of expression, shows the value of free speech in a different light, and makes particular features of freedom of speech particularly salient. These features include interactivity, mass

81 See Beth Simone Noveck, Designing Deliberative Democracy in Cyberspace: The Role of the Cyber-Lawyer, 9 B.U. J. SCI. \& TECH. L. 1, 5, 8-10 (2003).

82 See, e.g., LESSIG, CODE AND OTHER LAWS OF CYBERSPACE, supra note 17, at 3-8. 
participation, nonexclusive appropriation, and creative transformation. This in turn leads us to a new conception of the purposes of freedom of speech, which I have called the promotion of a democratic culture.

However, these same technological changes also create new forms of social conflict, as business interests try to protect new forms of capital investment. This leads, in turn, to attempts to protect and expand rights in intellectual property and in the control of telecommunications networks. These rights claims clash with freedom of speech values in ever new ways; and the attempt to protect property rights in capital investment leads to competing visions of what freedom of speech is and what it is not.

Finally, as technological innovation alters the social conditions of speech, the technological and legal infrastructure that supports the system of free expression becomes foregrounded. As a result, free speech values must be articulated and protected in new ways, in particular, through the design of technology and through legislative and administrative regulation of technology, in addition to the traditional focus on judicial doctrines that protect constitutional rights.

As the world changes around us, as the possibilities and problems of new technologies are revealed, our conception of the free speech principle begins to change with them. Our sense of what freedom of speech is, why we value it, and how best to preserve that which we value, reframes itself in the changing milieu. And as we respond to these changes, retracing our steps and rethinking our goals, we eventually come to understand what the free speech principle is about, and more importantly, what it always was about but only now can be adequately expressed. That experience is not the experience of making something new. It is the experience of finding something old, of recognizing principles and commitments already dimly understood, which suddenly are thrown into sharper focus by the alteration in our circumstances.

The arguments in this essay are an outgrowth of a more general way of thinking about rights and fundamental liberties. Call it a dynamic theory of rights, or rights dynamism. Rights dynamism is the claim that the nature, scope, and boundaries of rights, and in particular fundamental rights like speech, are continually shifting with historical, political, economic, and technological changes in the world. ${ }^{83}$ The content and scope of those

83 For a more general account of legal historicism, of which dynamism is a special case, see Jack M. Balkin \& Sanford Levinson, Legal Historicism and Legal Academics: The Roles of Law Professors in the Wake of Bush v. Gore, 90 GEO. L.J. 173, 174-75 (2001) (defining legal historicism as claim that legal conventions and forms of legal argument gradually change in response to political and social struggles that are waged through them). See also PAUL BREST, SANFORD LEVINSON, J.M. BALKIN \& AKHIL REED AMAR, Processes of CONSTITUTIONAL DECISIONMAKING, at Xxxi-Xxxii (4th ed. 2000) (articulating theory of constitutional historicism). I am using the term "dynamism" rather than historicism in order to emphasize two separate 
rights, the interests they protect and the interests they leave unprotected, change as the language of rights and the enforcement of rights are placed in new contexts, and are invoked by different actors and different economic and social interests. Hence it is necessary for those who believe in the language of rights - and in the recognition and protection of basic and fundamental rights such as the liberty of expression-to rethink the premises of rights as the discourse of rights is invoked in emerging social contexts. For only through constant rethinking, in the face of changed circumstances, can we recall and rediscover what our deepest commitments truly are. What appears to be change is actually continuity; what appears to be revision is actually the deepest form of remembrance.

Most people, I suspect, will be wary of such historicism for an obvious reason. If rights are truly fundamental, and therefore worth protecting and fighting for, their content should be relatively fixed over time. We should not alter what is protected and what is not protected every time we come across a result we do not like, for if the content and scope of basic liberties can change, and if they must be retheorized and reconceptualized in each generation, who is to say that they will not be eroded, undermined, or effectively destroyed? Even if we only set out to change our attitudes about these basic rights at the margins, jettisoning some elements and adding others, who is to say that we will not throw out the baby with the bathwater? What security do we have in rights that can change as history changes?

I do not underestimate these worries, or the force of these concerns. They describe a great danger for liberty. They articulate the threat that all historicism (and all relativism) present to principle and to principled argument. But here is the catch. If we do not, from time to time, rethink the scope and extension of our basic liberties, their scope and extension will change anyway, whether we like it or not. For faced as we are with social, technological, and economic change, other people will be busily rewriting rights and turning them to their own advantage. And if we do nothing to contest their work in an altered environment, we will soon find ourselves living with a set of fundamental rights framed and shaped according to their interests and their agendas.

Rights are a form of discourse, a way of thinking about the needs of social order and human liberty in the context of a changing world. Rights are also a source of power-first, because they are a powerful form of

points: First, rights dynamism is internal to participants in the practice of rights discourse rather than a stance that merely studies the discourse from the outside with no particular stake in its outcome. Second, rights dynamism is forward-looking, concerned with the future of a practice whose full contours cannot be known in advance, rather than a backward-looking historicism that attempts to articulate and comprehend changes that occurred in the distant past. 
rhetorical appeal, and second, because the enforcement of rights recognized by the state is backed up the power of the state. Because of this, rights and rights discourse are continually invoked by people and by groups to further their ideals, interests, and agendas: For the discourse of rights is the discourse of power, the restructuring of rights is the restructuring of power, and the securing of rights is the securing of power.

As people face new problems and altered circumstances, they naturally invoke elements of existing rights discourses, hoping to extend them in preferred directions in order to articulate their moral and political ends and further their favored policies. They call upon the struggles and victories of the past and the legal concepts of the present in order to shape the future. This is as true of groups and interests we like as those we oppose.

Rights are not simply a fixed set of protections that the state affords or fails to afford. Rights are a terrain of struggle in a world of continuous change- a site of ongoing controversies, a battleground where the shape and contours of the terrain are remade with each victory. Rights, and particularly fundamental rights, far from being fixed and immovable, are moving targets. They are worth fighting over because the discourse of rights has power and because that discourse can be reshaped and is reshaped through intellectual debate and political struggle.

This feature of rights discourse is a special case of what I have called "ideological drift." The liberty of expression has no special security from such drift. To the contrary, it is subject to the pushing and pulling, the reconceptualizations and transvaluations to which all other rights are heir. The capitalist theory of rights that I have described previously is only the most recent example.

If one loves liberty, and believes that there are basic liberties that every decent society should recognize and protect, one must also recognize that the rhetorical reconstruction of rights will be ongoing whether we or others perform it. What we do not do for ourselves will surely be done to us.

Eternal vigilance, it is often said, is the price of liberty. But that vigilance is of two forms. The first kind of vigilance is the vigilance of the guardian, who attempts to ensure that every feature and aspect of liberty is preserved today just as it was in ages past. But the second and far more important form of vigilance is the vigilance of the guide or explorer, who helps others make the transition from the world they knew to the one that awaits them.

People are continually thrown into new circumstances and they must articulate the meaning of liberty in those new circumstances. The task of such a guide or explorer is to find the meaning of the old in the new, and to prevent the rhetoric of liberty from becoming liberty's prison. Such 
vigilance is every bit as important as the vigilance of the guardian. And this vigilance, too, is eternal, and its exercise, too, is the ineluctable price of liberty. The world will not stand still and let us enjoy our freedoms. It will continually make itself anew, and as it does, we must consider the everchanging predicament of liberty, and the ever new methods by which it may be augmented or curtailed.

The digital revolution is a revolution, and like all revolutions, it is a time of confusion, a time of transition, and a time of opportunity for reshaping the structures of the economy and the sources of power. As a time of opportunity it is also a time of opportunism, a period in which the meaning of liberty of expression will be determined for good or for ill, just as the meaning of economic liberty was determined in an earlier age. Make no mistake: The digital age will change the meaning of freedom of expression. The only question is how it will change. If we do not reconsider the basis of liberty in this age, if we do not possess the vigilance of the guide as well as the guard, we shall end up like every person who travels through the wilderness without a compass, or through the forest without the forester. We shall end up lost. 